\title{
Pliocene and Pleistocene chronostratigraphy and paleoenvironment of the central Arctic Ocean, using deep water agglutinated foraminifera
}

\author{
John R. Evans ${ }^{1,2}$ and Michael A. Kaminski ${ }^{1}$ \\ ${ }^{l}$ Department of Geological Sciences, University College London and \\ Birkbeck College Research School, Gower Street, London, WCIE 6BT, United Kingdom \\ ${ }^{2}$ Environmental Research Centre, Department of Geography, \\ University of Durham, South Road, Durham, DHI 3LE, United Kingdom
}

\begin{abstract}
Deep-water agglutinated foraminifera (DWAF) were studied from Cores PS2177-5, PS2200-5, PS2212-3 and PS2185-6; from the R/V POLARSTERN ARK-VIII/3 Cruise in the central Arctic Ocean. The sediments were non-calcareous containing a sparse assemblage of eleven DWAF species. A chronostratigraphic framework is presented for Cores PS2200-5 and PS2185-6. Paleoenvironmental data suggests a bathyal environment $(2000-4000 \mathrm{~m})$ affected by water masses in the Arctic Ocean. The taxonomy of all of the DWAF found is presented and illustrated. A new species of the Family Trochamminidae; Trochammina lomonosovensis $\mathrm{n}$. sp. is described and illustrated.
\end{abstract}

\section{INTRODUCTION}

Over the past few years, numerous studies have documented Recent benthic foraminifera from the Arctic Ocean, for example (Lagoe 1977, 1979). The deep water agglutinated foraminifera (DWAF) from the central Arctic Ocean have so far received limited attention. The aim of this study is to contribute to an overview of DWAF from the Arctic Ocean (see also Evans et al. 1995). The ultimate goal of this work is to construct a paleoenvironmental and biostratigraphical framework for the region for the Pliocene and Pleistocene.

A large and comprehensive database has been compiled by Schröder-Adams and McNeil, (1994) for Oligocene to Miocene agglutinated foraminifera from the Beaufort-Mackenzie Basin. Bergsten (1994) documented DWAF from Recent sediments of the Yermak Plateau, Morris Jesup Rise and Amundsen Basin. Scott and Vilks (1991), documented agglutinated foraminifera from Recent sediments collected during the CESAR, LOREX and Fram II, III expeditions. Scott et al. (1989) described benthic foraminifera from the CESAR expedition, and found DWAF, dominated by Cyclammina in Units A2-AB (Clark 1980) in CESAR Core 14. The agglutinated foraminifera were not described in detail, as they only made up a small percentage of the total foraminiferal population. Therefore, previous workers have not concentrated solely on Pliocene and Pleistocene DWAF from sediments of the central Arctic Ocean.

During the summer of 1991 the R/V POLARSTERN took part in the ARK VIII/3 cruise in the central Arctic Ocean. A transect of cores were obtained from the Lomonosov Ridge, Morris Jesup Rise to the Yermak Plateau; from which the piston cores 2177-5 and Cores PS2185-6, PS2200-5, and PS2212-3 were taken. This paper focuses on the latter three cores, and compares with data already presented by Evans et al. (1995).

\section{Location}

Core PS2200-5 was collected from the Morris Jesup Rise, (text-fig. 1), the second, Core PS2212-3 is from the Yermak Plateau and Core PS2185-6 is from the Lomonosov Ridge. Core PS2177 was also from the Lomonosov Ridge [Evans et al. (1995)]. The position, water depth and recovery for the cores is given in Table 1.

\section{Lithology}

The sediments of the three cores can be subdivided into four lithological units, which are typical for central Arctic Ocean sediments. The sedimentary units were described using a standard core description technique and no attempt was made by The Shipboard Party to correlate with the Clark Lithostratigraphic classification (Clark 1980) as this would require some element of interpretation (personal communication, Dr. Robert Spielhagen, July 1996). The lithological units present in the cores are 'sandy, silty mud', 'clay', 'clayey mud' and 'silty mud'. Some of the cores contain dropstones, calcareous concretions, and sand lenses. General lithological descriptions are illustrated in text-figures 2, 3 and 4 .

\section{METHODS}

Each sample was washed over a $63 \mu \mathrm{m}$ sieve, dried, and residues picked for foraminifera. This was carried out by technicians at the United States Geological Survey, Reston. The average sample weights for Core PS2200-5 is 70g and Core PS2212-3 is 40g, sample weights for Core PS2185-6 were not recorded by the technicians. Specimens were mounted in cardboard microscope slides, and are housed in the micropaleontology collections of University College London.

In this study 11 species of DWAF, including one new species, are described from 53 samples collected from Core PS2177-5; 


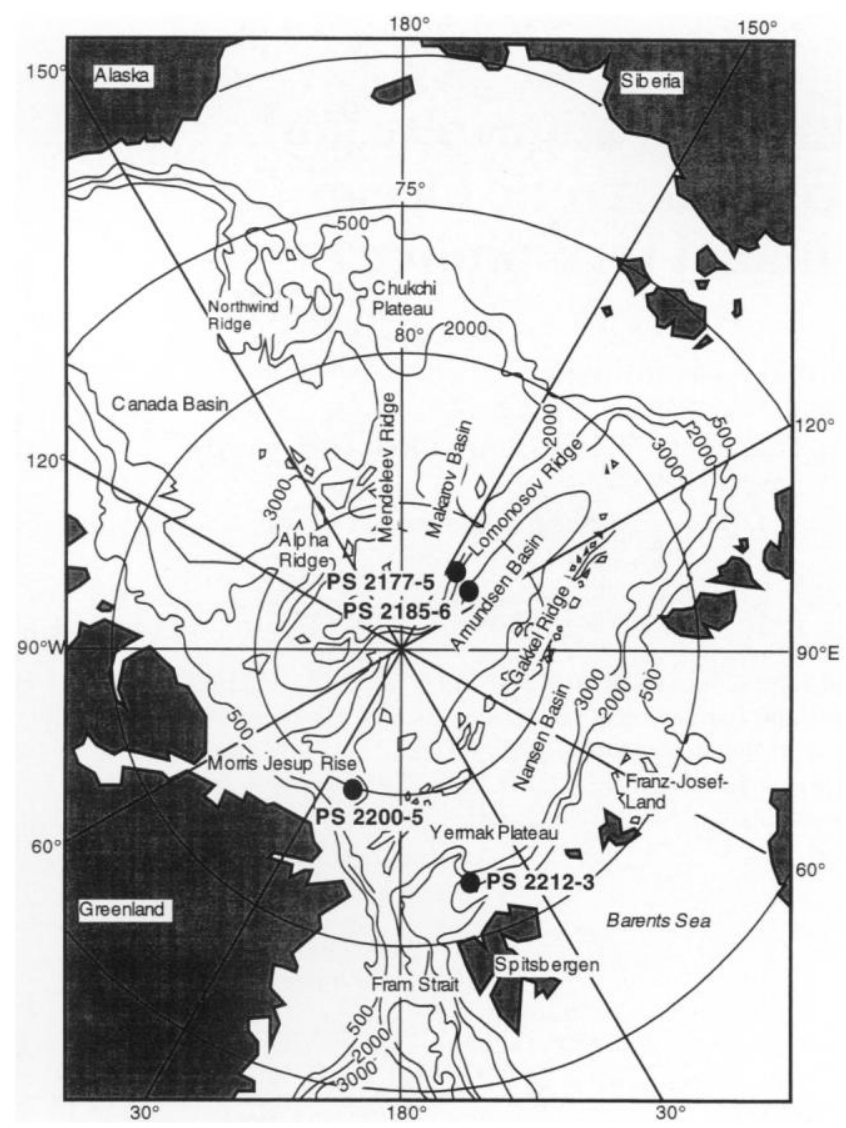

TEXT-FIGURE 1

Map showing location of cores in the Central Arctic Ocean.

132 samples from Core PS2200-5; and 37 samples from both Core PS2212-3 and Core PS2185-6.

The taxonomy of the DWAF is based on Loeblich and Tappan (1987) using their morphological characteristics as the main criteria for their classification. The classification of agglutinated foraminifera using solely the cement morphology (Loeblich and Tappan 1989) has not been used, as this is not generally accepted (Bender 1995). The classification of the agglutinated foraminifera remains a problem and further research needs to be carried out to achieve a standard for classification.

\section{RESULTS}

The three cores contain fifteen species of DWAF. The dominant species in Cores PS2200-5 and PS2185-6 is Cyclammina pusilla Brady, followed by Alveolophragmium polarensis O'Neill 1981. The latter dominates Core PS2212-3. The abundance of all the species is described from the bases of the cores to their tops. The taxonomy for all of the species presented in this paper is discussed in the taxonomy section, including the designation of the new trochamminid species, Trochammina lomonosovensis sp. nov.

\section{Core PS2200-5 (KAL) - Morris Jesup Rise}

The core was found to contain eleven species of DWAF in eighty samples out of 132. These are Cyclammina pusilla Brady, Alveolophragmium polarensis O'Neill, Psammosphaera fusca Schulze, Glomospira charoides Parker and Jones, G. gor- dialis Parker and Jones, Rhabdammina discreta Brady, $R$. antarctica Saidova, Rhabdammina sp. 1 and Trochammina lomonosovensis sp. nov., Cyclammina sp. 1 and Recurvoides contortus Earland 1934.

The species vary in abundance throughout the core, but assemblages are dominated by $C$. pusilla. This species is abundant from the base of the core $(693 \mathrm{~cm})$, producing a peak at Sample $318 \mathrm{~cm}$, with 273 specimens (av. sample weight $=70 \mathrm{~g}$, text-fig. 5 ). This corresponds with the peak in total abundance of the species in the core, (text-fig. 5). There is then a large gap, where it is not observed, however, it is re-occurs in Samples $168 \mathrm{~cm}$ and $18 \mathrm{~cm}$, represented by single specimens respectively (text-fig. 5). Altogether there are 3906 specimens of $C$. pusilla, and it comprises $78 \%$ of the total DWAF assemblage.

Alveolophragmium polarensis is the second dominant species in the core. It is present from the base of the core, but fluctuates widely in its abundance in comparison with $C$. pusilla. It peaks in Sample $568 \mathrm{~cm}$, with 155 specimens. There are gaps in its record, with smaller numbers at Samples $468 \mathrm{~cm}$, (51 specimens); $338 \mathrm{~cm}$ (108 specimens), followed by low abundance values of the species through to Sample $133 \mathrm{~cm}$. It then re-appears at Sample $8 \mathrm{~cm}$ (Table 2). This makes it one of the two species which occurs at the youngest level in the core. Alveolophragmium polarensis represents $15 \%$ of the total DWAF assemblage in this core.

The other nine species present in the core have limited range and a low number of specimens. However, the most abundant of these is Psammosphaera fusca Schulze, which is present from the base to the top of the core. There is only a single specimen at Sample $693 \mathrm{~cm}$. The abundance slowly rises to 20 specimens at Sample $663 \mathrm{~cm}$. This is then followed by the highest abundance of the species in the core, at Sample $583 \mathrm{~cm}$ with 41 specimens (text-fig. 5). Psammosphaera fusca is subsequently present in small numbers, with peaks at Sample $498 \mathrm{~cm}$ (10 specimens); and Sample $398 \mathrm{~cm}$ (12 specimens), it re-appears at Sample $8 \mathrm{~cm}$ with a single specimen. The accessory species are present throughout the core, with Trochammina lomonosovensis appearing at Sample $18 \mathrm{~cm}$ with four specimens. The abundance of these species is illustrated in a combined plot in text-figure 5 and presence in Table 2.

\section{Core PS2212-3 - Yermak Plateau}

Seven species are present in this core; Alveolophragmium polarensis, Psammosphaera fusca, Glomospira charoides, G. gordialis, G. saturniformis, Rhabdammina discreta and Rhabdammina sp. 1. Surprisingly, Cyclammina pusilla is absent from the core, which is unusual for the study area. Rare specimens of $G$. charoides have a final planispiral whorl coiled in a different plane, similar to the form described as $G$. saturniformis by Majzon (1943). It is not found in any of the other cores, and as it is only represented by three specimens. It is not included in the taxonomy section of this paper.

The dominant species, Alveolophragmium polarensis only occurs between $180 \mathrm{~cm}$ and $5 \mathrm{~cm}$, (text-fig. 6). The numbers of the specimens are low in comparison with Core PS2200-5, peaking in abundance at Sample $20 \mathrm{~cm}$, with 29 specimens (av. sample weight $=40 \mathrm{~g}$ ), obviously corresponding with the peak in total abundance (text-fig. 6). The species makes up $80 \%$ of the total assemblage, however, this may appear to be artificially high, compared with Core PS2200-5, as only 119 specimens were found in the core, compared with 5036 in the first core. Many of 


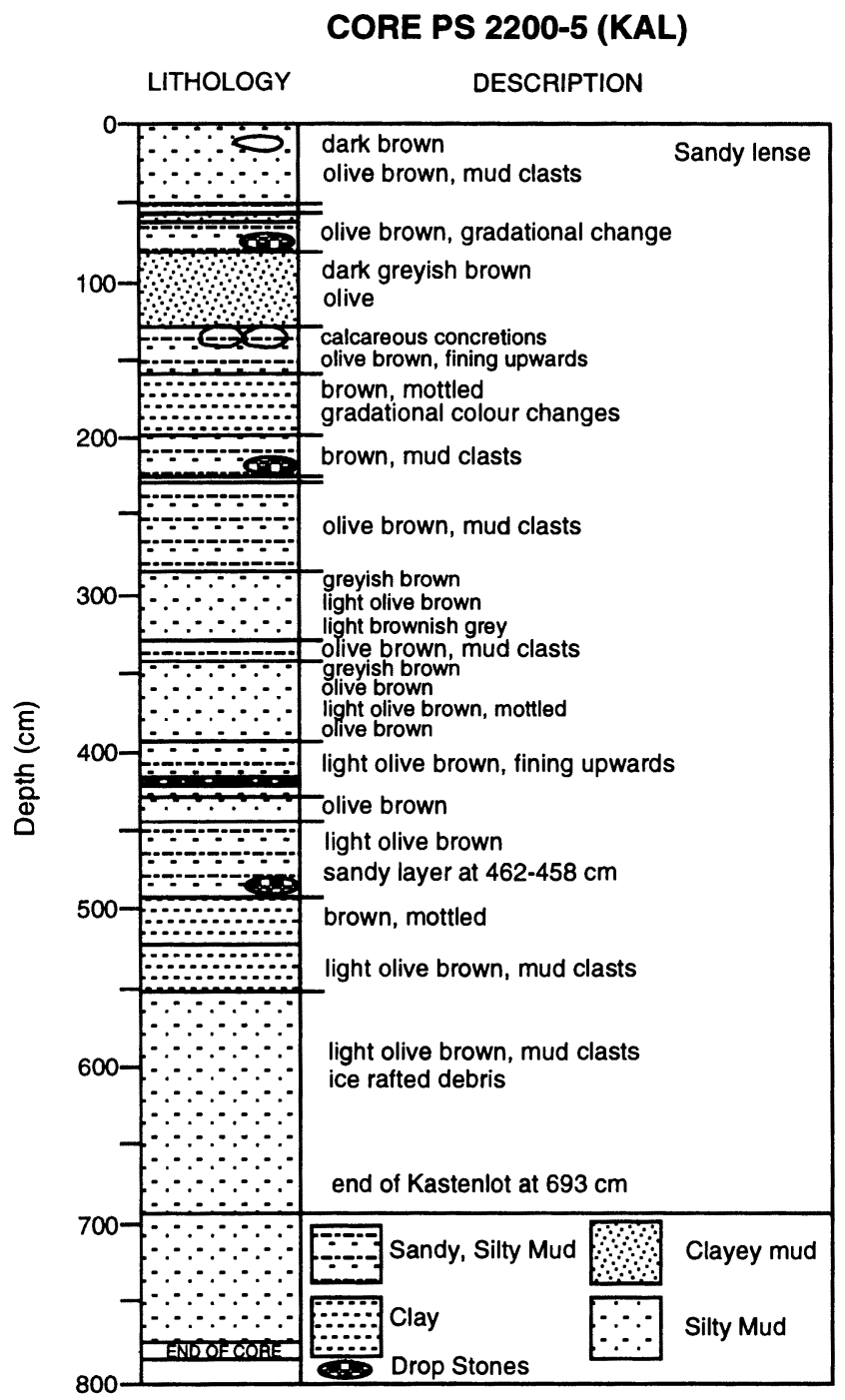

TEXT-FIGURE 2

Lithological log for Core PS2200-5 (KAL).

the specimens are broken, and whole specimens are rare. However, a number of specimens from this core are described and illustrated in the taxonomy chapter.

The remaining species are only present at certain horizons, notably $P$. fusca, occurring at Sample $40 \mathrm{~cm}$, with five specimens; and $G$. charoides, $G$. gordialis and $G$. saturniformis all present at Sample $340 \mathrm{~cm}$, with one, three and one specimens respectively. Rhabdammina discreta yielded two and eight specimens at two horizons, Samples $360 \mathrm{~cm}$ and $250 \mathrm{~cm}$ respectively; and $R$. antarctica appeared at Sample $340 \mathrm{~cm}$ with four specimens.

\section{Core PS2185-6 - Lomonosov Ridge}

The DWAF in this core are the second most abundant of the cruise, with thirteen species present in 26 samples. The core contains 37 samples in total. As with Core PS2200-5, the assemblage is dominated by $C$. pusilla, followed by Alveolophragmium polarensis. The core is barren of DWAF above Sample $131 \mathrm{~cm}$. Cyclammina pusilla ranges from the base of the
CORE PS 2212-3 (KAL)

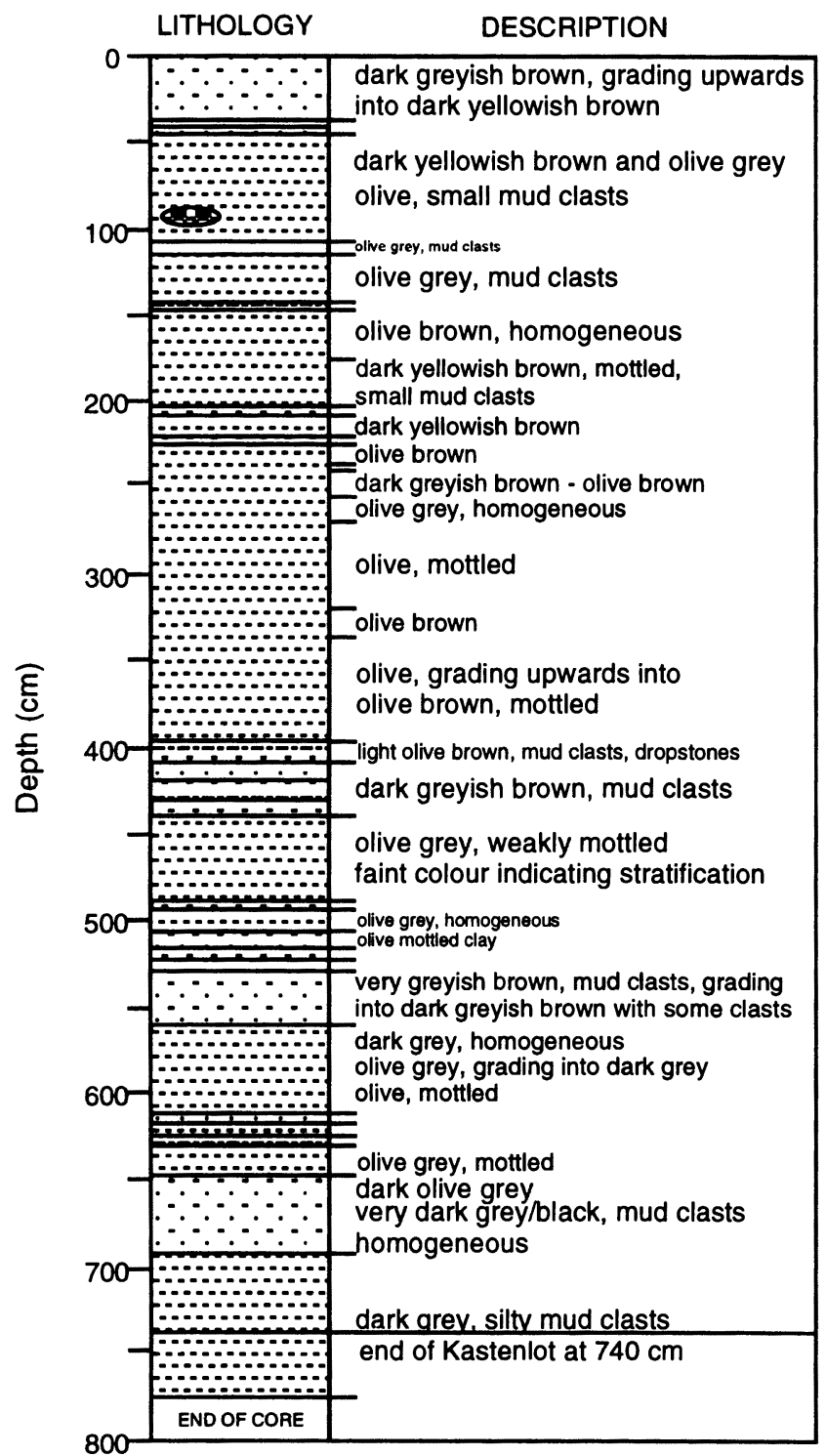

TEXT-FIGURE 3

Lithological log for Core PS2212-5 (KAL).

core, $(751 \mathrm{~cm})$, to Sample $231 \mathrm{~cm}$. It varies in abundance, having initial low numbers at the base and rises sharply to peak in abundance at Sample $671 \mathrm{~cm}$, with 136 specimens (text-fig. 6). Its abundance then declines, fluctuating between Sample $651 \mathrm{~cm}$, 25 specimens and Sample $411 \mathrm{~cm}, 20$ specimens, before peaking again at Sample $391 \mathrm{~cm}$, which contains 121 specimens (textfig. 6). It remains at low values, and finally peaks and disappears at Sample $231 \mathrm{~cm}$, with 111 specimens. Altogether, 1209 specimens of $C$. pusilla were recovered from the core, comprising $82 \%$ of the DWAF assemblage. As with Core PS2212-3, this appears to be artificially high, however, the actual number of specimens obtained from the core is low in comparison with Core PS2200-5.

Alveolophragmium polarensis has a discontinuous abundance record, first appearing just above the base at Sample $731 \mathrm{~cm}$, 


\section{CORE PS 2185-6 (KAL)}

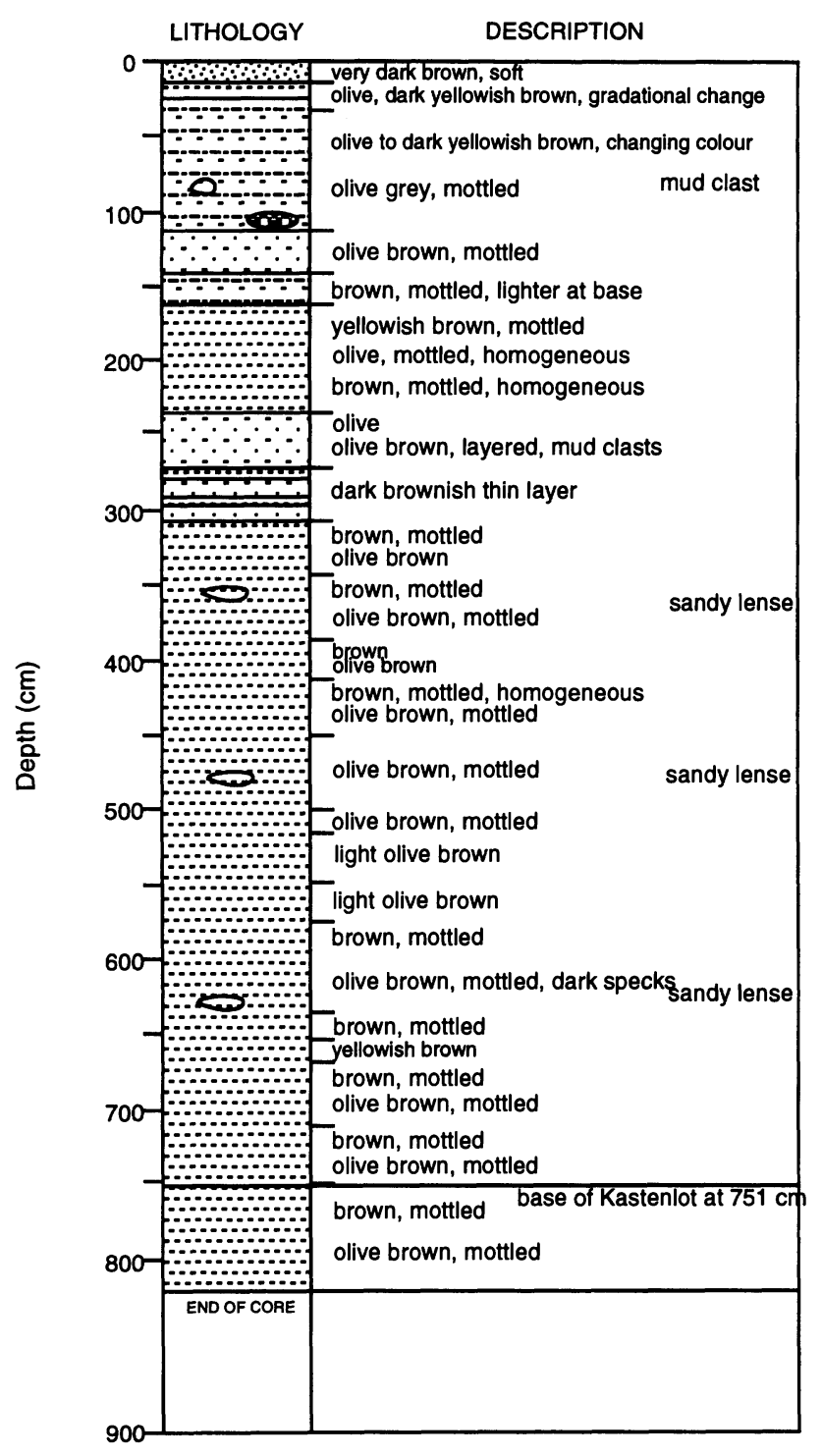

TEXT-FIGURE 4

Lithological log for Core PS2185-6 (KAL).

with 95 specimens. As with the other two cores, the specimens of this species are often fragmented, probably owing to its large size or related to sampling processes. This relatively high abundance, sharply drops to 14 specimens in the following sample, which is then proceeded by a large gap until Sample $311 \mathrm{~cm}$, where 78 specimens were retrieved. The high value at this horizon, combined with 94 specimens of $C$. pusilla, produce the peak in overall DWAF abundance, (text-fig. 6). This differs to the other two cores, where the peak in total abundance has been solely as result of the highest value of $C$. pusilla at this point. However, Alveolophragmium polarensis constitutes only $8 \%$ of the total DWAF population in the core, which is lower than in Core PS2200-5. The value at Sample $311 \mathrm{~cm}$ drops until Samples $231 \mathrm{~cm}$ and $211 \mathrm{~cm}$, where there are 16 and six specimens respectively. This is the L.O. of this species.
Trochammina lomonosovensis has a wide occurrence in the core, appearing in Sample $751 \mathrm{~cm}$, where 4 specimens were found, and disappearing at Sample $131 \mathrm{~cm}$. This species occurs at the youngest horizon in the core, its abundance varies and peaks at 16 specimens in Sample $671 \mathrm{~cm}$, the same as for $C$. pusilla. Psammosphaera fusca is present from the base of the core up to Sample $471 \mathrm{~cm}$ (text-fig. 6), the number of specimens is low with a peak at Sample $531 \mathrm{~cm}$, with 15 specimens.

The abundance of the remaining species present, including two species of the genera Rhabdammina, and Glomospira; Cyclammina sp. 1, 2, and 3; and Cystammina pauciloculata (Brady) are low. These species do not make up more than $3 \%$ of the total DWAF assemblage.

\section{INTERPRETATION}

\section{Chronostratigraphy}

The dating of these three cores and others from the ARK VIII/3 has been problematic, however, some work has been carried out in the past, including Gard (1988) and Gard and Backman (1990) using nannofossil biostratigraphy and Stein et al. (1994a) using stable isotope stratigraphy. Cronin et al. (1995) has shown that recent studies of stable isotopes, paleomagnetic stratigraphy and micropaleontology of sediments from the Eurasian Basin have facilitated the task of constructing a chronostratigraphic framework for the Arctic Ocean. It has been demonstrated that by using a variety of methods Arctic Ocean sediments can be correlated to the standard timescale. A chronostratigraphic framework has been assembled by Nowaczyk et al. (1994) using magnetostratigraphy, Frederichs (1995) using rock magnetic parameter variation data, Stein et al. (1994a, b) using accelerator mass spectrometer (AMS) dating and stable oxygen isotopes $\left({ }^{18} \mathrm{O}\right)$; and Gard (1993) using nannofossil biostratigraphy. However, Stein et al. (1994a) stressed that stable isotope records from the Arctic Ocean might be strongly influenced by local processes such as meltwater discharge. This generates difficulties for correlating the cores using stable isotope stratigraphy. In consequence to this, Stein et al. (1994a) used AMS ${ }^{14} \mathrm{C}$ dating, providing approximate calibration of the preliminary isotopic stages. The stable isotope method can be used to estimate average sedimentation rates for the cores, however, this depends on the presence of the dominant Arctic planktonic foraminifera, Neogloboquadrina pachyderma sin. This limits the dating of the complete length of the three cores as this species is only present in the upper sections of the cores. In addition, data from rock magnetic parameters variations in the sediments, have been used by Frederichs (1995) to generate age models. This has been carried out for all three of the cores studied and has proved to be one of the more precise methods used for the dating of the cores.

\section{Core PS2200-5 (KAL) - Morris Jesup Rise}

The sedimentation rates for the core and a tentative age model were proposed by Cronin et al. (1994) using ostracoda biostratigraphy. Sedimentation rates were assumed to average $1.5 \mathrm{~cm} / 1000 \mathrm{yr}$. This age model suggested that the upper $400 \mathrm{~cm}$ of the core represents the last three interglacial periods, oxygen isotope Stages 7, 5 and 1 (the Holocene). Cronin et al. (1994) believed that there is a recognisable faunal sequence representing transitions from a glacial or cool to a warm, interglacial period. These are recognised at boundary terminations between Stages $5 \mathrm{~d}$ to $5 \mathrm{c}$ and the boundary between Stages 2 and 1 and a transition within Stage 7. These isotopic constraints for the age 


\section{CORE PS 2200-5 (KAL)}
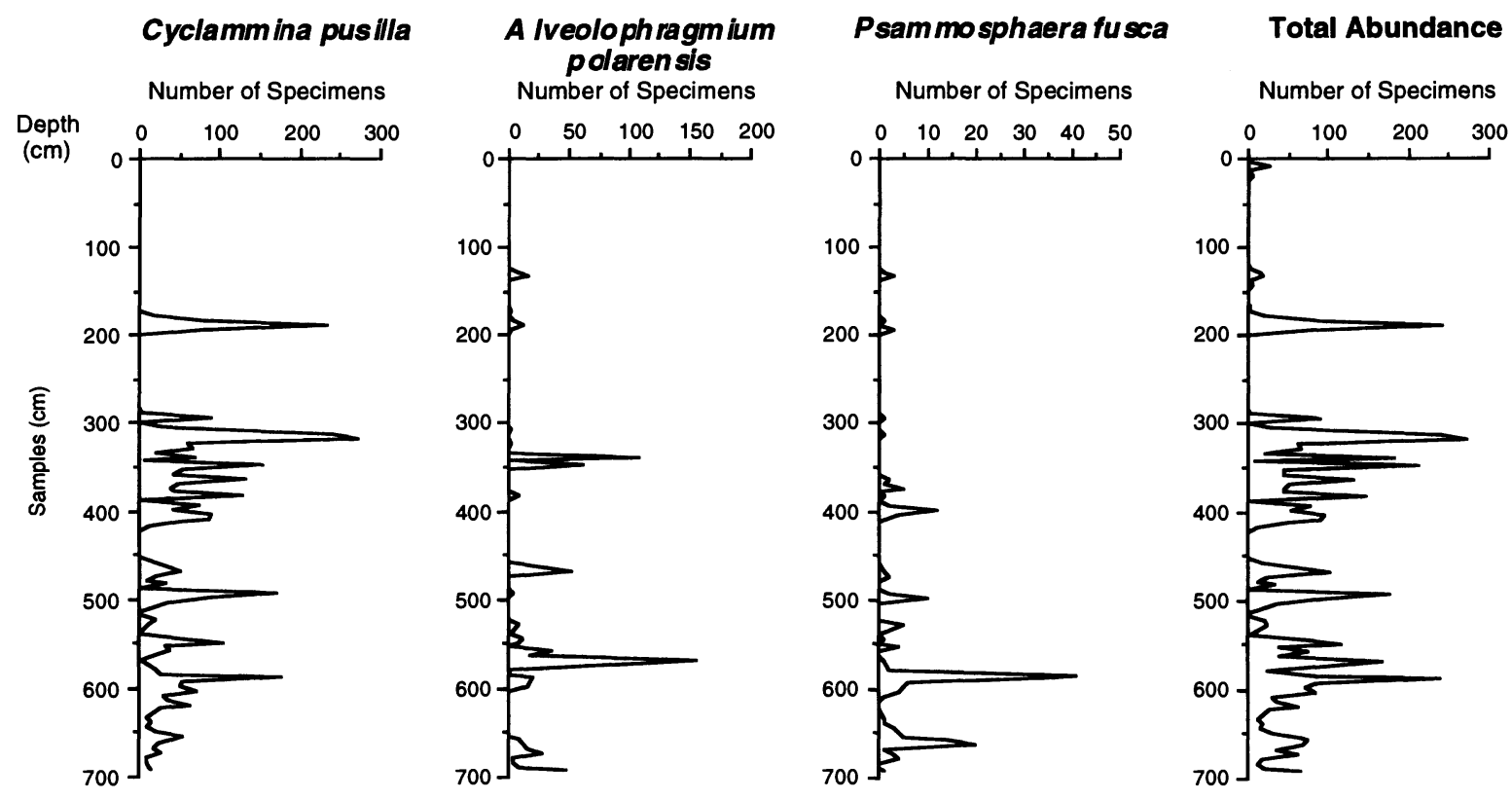

No abundance line reflects absence of species Average Sample Weight $=70 \mathrm{~g}$

TEXT-FIGURE 5

Abundance plots of species in core PS2200-5 (KAL).

of the upper half of core help calibrate with the biostratigraphy of the core. However, the record from the base of the core to Sample $383 \mathrm{~cm}$, is not constrained isotopically.

The variation of rock magnetic parameters and paleomagnetic data enabled Frederichs (1995) to generate a chronostratigraphic model. Frederichs presented two age models, an older and a younger, however, he noted (personal communication, August 1995), that it is difficult to decide which of the two models is correct. Since Cronin et al. (1994) identified the isotopic stages discussed above, we prefer to use the younger of the age models. In addition, the distribution of the DWAF through the core appear to correlate well with the warm and cold periods.

The three dominant species in Core PS2200-5, C. pusilla, Alveolophragmium polarensis and $P$. fusca are present in significant numbers from the base of the core until $118 \mathrm{~cm}$, (text-fig. 7). According to Frederichs $(1995)$ the base $(693 \mathrm{~cm})$ region of the core up to $600 \mathrm{~cm}$, represents isotopic Stage 14 . This is a glacial period where the amount of ice sheet coverage would have been high, with a corresponding amount of terrigenous, clastic material and particulate organic matter reaching the sea floor. This should have the effect of reducing the accumulation rates of the sediments and foraminifera, which is the case for, the three dominant species of DWAF throughout the period.
Cyclammina pusilla, $P$. fusca and $A$. polarensis show abundance peaks at $590 \mathrm{~cm}, 580 \mathrm{~cm}$ and $565 \mathrm{~cm}$ respectively (text-fig. 7), which corresponds with isotopic Stage 13, an interglacial period. Following this the DWAF are low in abundance, corresponding with isotopic Stage 12, a glacial period. During isotopic Stage 12, the Emperor geomagnetic event occurred, which ranged from $470-460 \mathrm{Ka}$. This low abundance occurs until $495 \mathrm{~cm}$, where $C$. pusilla and $P$. fusca suddenly increase in numbers. This subsequent higher abundance reflects the higher temperatures and more favourable environmental conditions during an interglacial period, isotopic Stage $11(505 \mathrm{~cm}$ $439 \mathrm{~cm})$. It should be noted that the Biwa III geomagnetic event (395-370 Ka.) occurred during isotopic Stage 11, which may have borne some climatic influences on the Arctic Ocean. The abundance of the DWAF fluctuates from this point, through isotopic Stage 10, until it reaches $410 \mathrm{~cm}$, which corresponds with the base of isotopic Stage 9. This is a relatively abundant period, dominated by $C$. pusilla and $P$. fusca, and as noted by Frederichs corresponds with the Biwa II event (329-301 Ka.) Isotopic Stage 8 has a very low abundance value for the DWAF and has a very narrow range $(350 \mathrm{~cm}-340 \mathrm{~cm})$. This stage is proceeded by the highest abundance in the core, where $C$. pusilla is represented by approximately 273 specimens, during the middle of isotopic Stage 7, an interglacial. This suggests that Stage 7 might have generated optimum environmental conditions for the DWAF, resulting in high benthic biomass. Above Stage 7, 


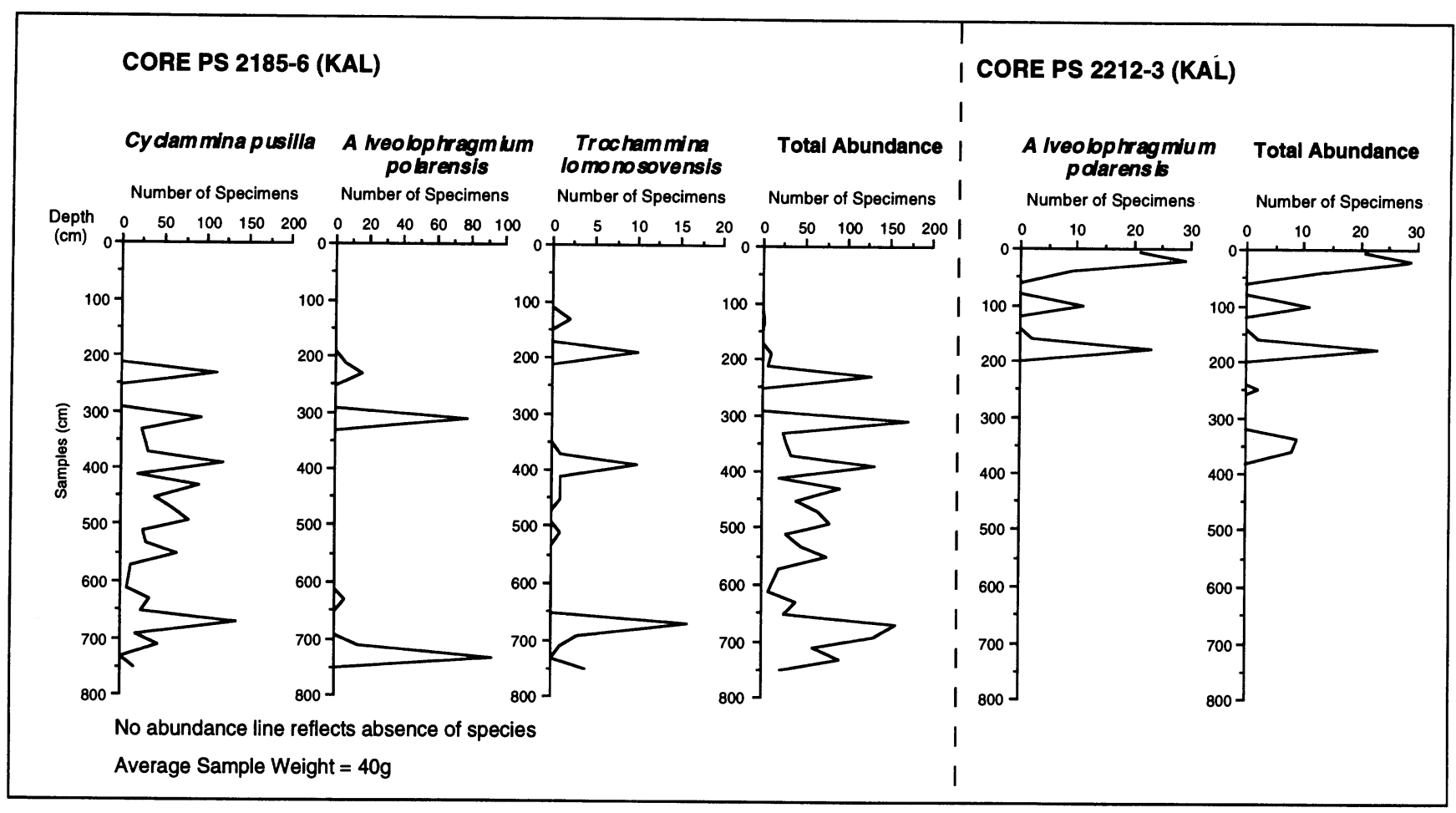

TEXT-FIGURE 6

Abundance of species in cores PS2185-6 (KAL)/PS2212-3 (KAL).

the DWAF are present, but are sparse for an interval of approximately $100 \mathrm{~cm}$. This is proceeded by high abundance peak represented by $C$. pusilla which corresponds with the base of isotopic Stage 5. After this point, the DWAF only occur in very low amounts and are lastly observed in Stage 1, at the top of the core.

It is apparent that our DWAF records correlate well with Frederichs' younger chronostratigraphic model. The highest abundance peaks occurred during the interglacial sediments and the accumulation rate of the DWAF is generally low in the glacial sediments. The fact that they were present at the beginning of some glacial periods, suggests that they were able to tolerate the initial temperature changes at the interglacial/glacial transitions. However, once the temperature dropped further, with the formation of permanent ice cover accompanied by deteriorating sea-floor conditions, the DWAF assemblages declined markedly in numbers. There does not appear to be any strong lithological correlation with the glacial/inter-glacial episodes through the core.

\section{Core PS2212-3 (KAL) - Yermak Plateau}

The amount of data available generated from the study of DWAF in this core is limited in comparison with the other cores, however, Nowaczyk and Baumann (1994) indicated by using nannofossil and ${ }^{10} \mathrm{Be} /{ }^{230} \mathrm{Th}$ stratigraphy, that the core ranges from isotopic Stage 6 up to Stage 1, which included four geomagnetic polarity events within the Brunhes Chron. The occurrence of the DWAF corresponds with the nannofossils. Nowaczyk and Baumann (1994) described their occurrence during the warmer interglacial periods, isotopic Stages 5e, 5a and 1. They noted that the nannofossils do not occur below this Stage and they left the extent of Stage 6 open ended. It is therefore not possible to delimit the maximum age of the core by this method. However, they suggest that the sediments recovered are not older than $170 \mathrm{Ka}$, based on chrono-magnetostratigraphic results. The authors carried out demagnetisation on the core at different levels $(10,20,35,50,65,80,100,200 \mathrm{mT})$ and the characteristic remnant magnetisation (ChRM) determined. In core PS2212-3, through using these methods and magnetic susceptibility, intervals of negative inclination were interpreted as records of geomagnetic polarity events within the Brunhes Chron. Nowaczyk and Baumann (1994) indicated that the Biwa I event (181-171 Ka.) lies in the lowermost part of the core, this is followed by the an excursion-like shallow positive inclination, corresponding with an event around 160-150 Ka. in Baffin Bay, Alaska and the Fram Strait. In addition, Nowaczyk and Baumann (1994) documented that the other dating methods consistently yielded age ranges of $128-118 \mathrm{Ka}$. for the Blake event, 86-72 Ka. for the Norwegian-Greenland Sea event, 43-34 $\mathrm{Ka}$. for the Laschamp event, and 29-24 Ka. for the Mono Lake event.

This age is further justified by Frederichs (1995). Using rock magnetic parameter variations, the estimation of sedimentation rates and re-plotting the data provided by Nowaczyk and Baumann (1994), Frederichs illustrated how the rock magnetic data corresponds with the proposed age model. The DWAF, although low in abundance and diversity, exhibit trends similar to the rock magnetic data. Using ChRM data, Frederichs (1995) was able to highlight the four geomagnetic polarity events within the Brunhes Chron identified by Nowaczyk and Baumann (1994). The first event in the core is the Blake event at $500-455 \mathrm{~cm}$ 


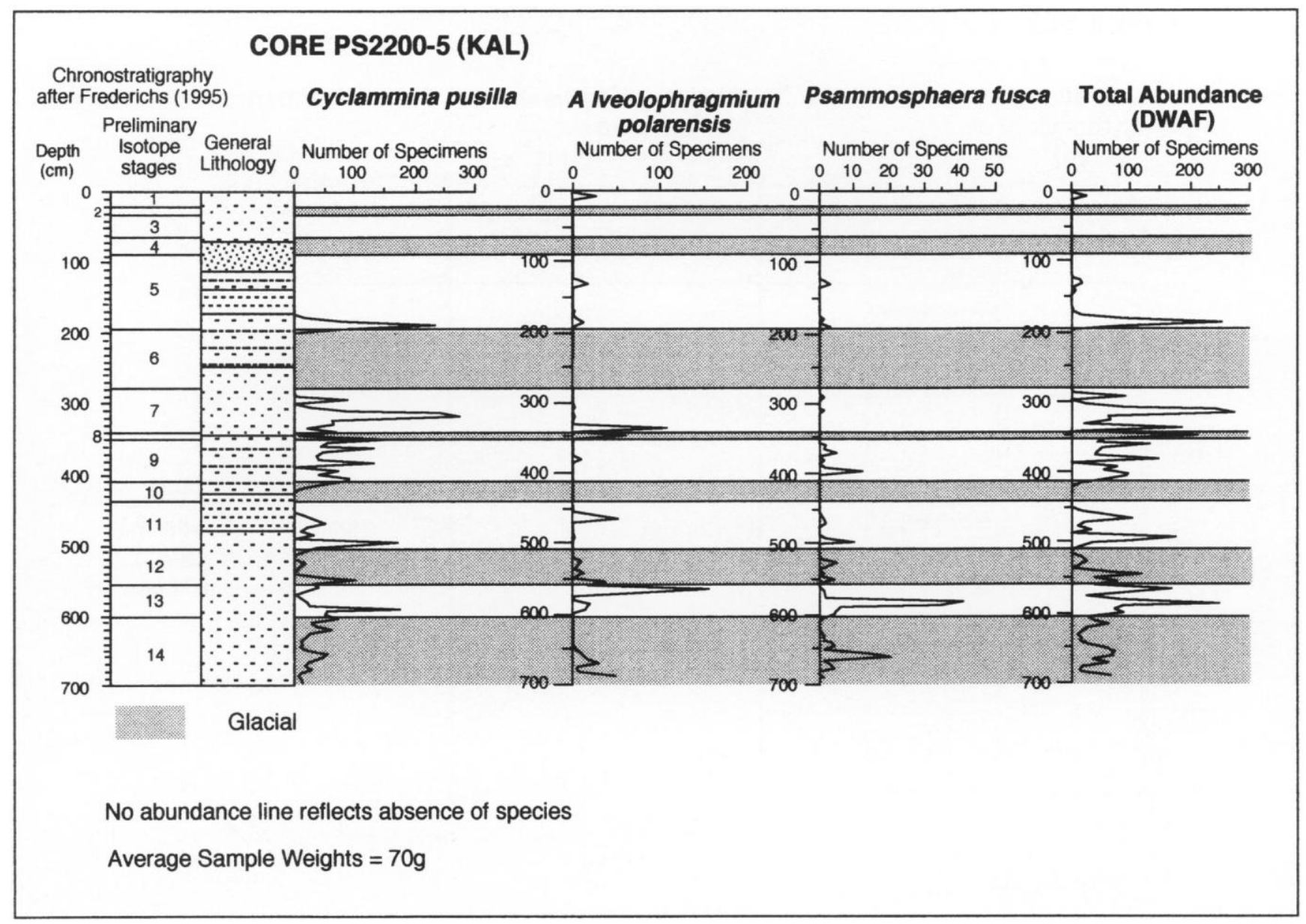

TEXT-FIGURE 7

Abundance of DWAF shown against isotopic stages for Core PS 2200-5 (KAL).

(128-117 Ka.), there is nothing in the DWAF record to correspond with this. The total abundance (text-fig. 8) shows a peak at $350 \mathrm{~cm}$, which occurs during the three-quarters the way through isotopic Stage 5. This is the first time the DWAF are observed in the core from the base. This total abundance peak is represented by Glomospira charoides and G. gordialis, and initially was thought to correspond with substage 5e interglaciation $(\sim 129-118 \mathrm{Ka})$, however, according to the timescale provided by Frederichs (1995) the abundance peaks occurs at $89 \mathrm{Ka}$. Keigwin et al. (1994) indicated that substage 5e represented conditions where there was less continental ice than today and that it was a peak interglacial within Stage 5. The DWAF data suggests that the peak may correspond with a slightly earlier substage, $5 \mathrm{a}$, which is also in accordance with the nannofossil biostratigraphy calculated by Nowaczyk and Baumann (1994).

A further suggestion is, the peak may correspond to the Norwegian-Greenland Sea event (86-72 Ka), which occurred during Stage 5, identified by Nowaczyk and Baumann (1994). However, it appears that the peak occurred three thousand years too early to correlate exactly with the event. The event gener- ated the Norwegian-West Spitsbergen current, which flows from the Norwegian and Greenland Sea to the Yermak Plateau. Nowaczyk and Baumann (1994) highlighted that there was a stratigraphic hiatus between $117-86 \mathrm{Ka}$. $(315 \mathrm{~cm})$ using the inclination and susceptibility data. However, the DWAF appear to contradict this as they occur at $350 \mathrm{~cm}$, which can be dated as 89 $\mathrm{Ka}$. The proceeding geomagnetic event, known as the Laschamp event, occurred between 42-37 Ka., Frederichs (1995) identified this between $160-131 \mathrm{~cm}$ in the core. This occurs within isotopic Stage 3 (59-23 Ka.), but does not correspond with a peak of DWAF. However, the Mono Lake event (26-23 $\mathrm{Ka}$.), which occurs between $111-119 \mathrm{~cm}$ in the core, highlights the abundance of the DWAF. The DWAF finally peak during Stage 1 .

\section{Core PS2185-6 (KAL)- Lomonosov Ridge}

The chronostratigraphy for this core was initially described by Stein et al. $(1993,1994 a)$ using ${ }^{18} \mathrm{O}$ stratigraphy for the upper $500 \mathrm{~cm}$ of the core suggesting that it represented isotopic Stages 1-7, which with hindsight is much too young. The treatment of the data available to them was comprehensive, however, further 


\title{
CORE PS2212-3 (KAL)
}

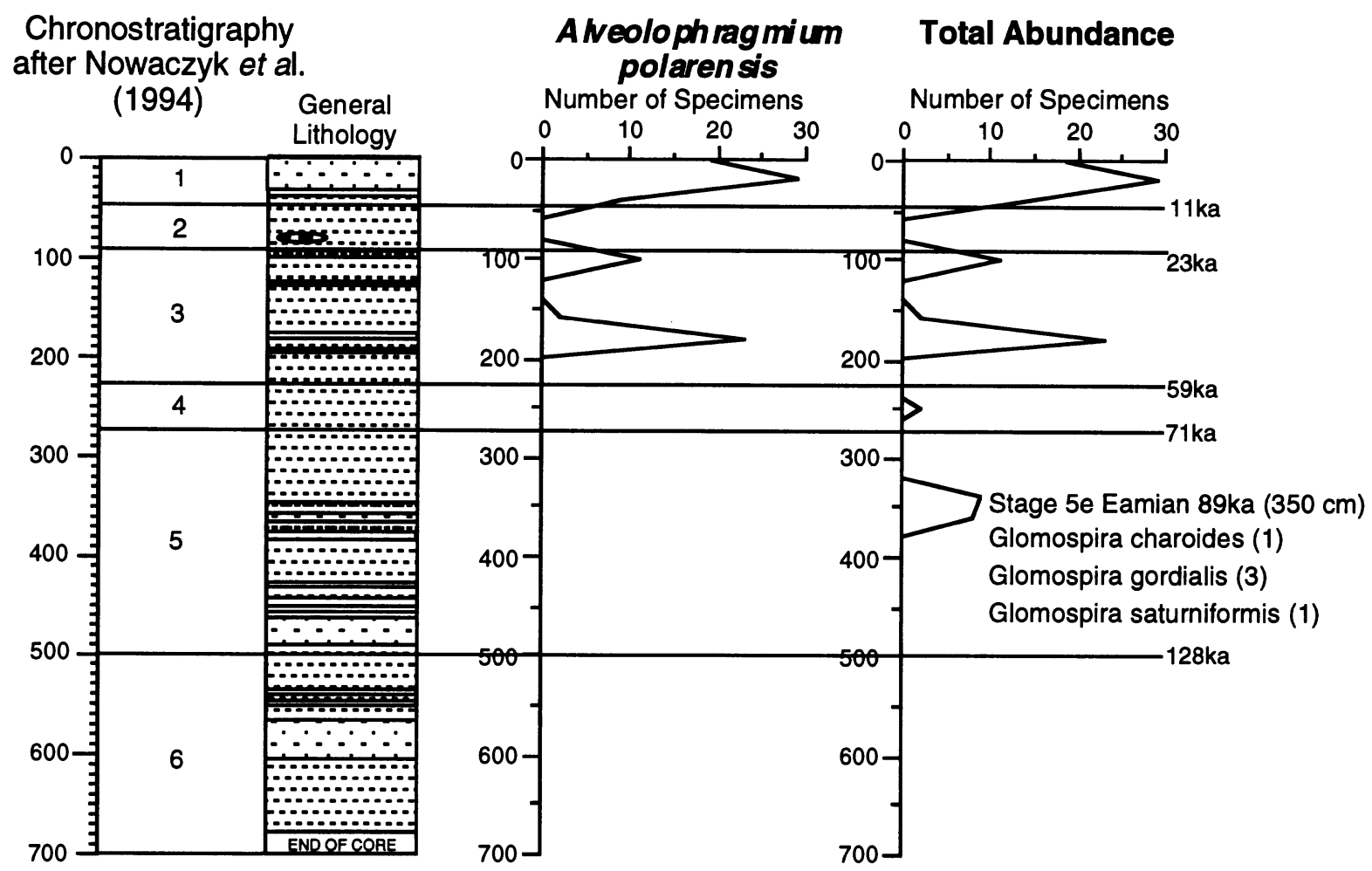

Palaeomagnetic events:

\author{
MonoLake $111-91 \mathrm{~cm}(26-23 \mathrm{ka})$ \\ Laschamp 160-131 cm (42-37ka) \\ Norwegian-Greenland Sea $335-280 \mathrm{~cm}(86-71 \mathrm{ka})$ \\ Blake 500-455 cm (128-117ka)
}

TEXT-FIGURE 8

Abundance of DWAF shown against isotopic stages for core PS2212-3 (KAL).

evidence from Frederichs (1995) suggested that the core is much older.

As with the other two cores, Frederichs (1995) presented two age models and was unsure as to which was correct. However, Spielhagen (personal communication, October 1995), indicated that the older of the two models correlated well with the available data. In accordance with Frederichs, Spielhagen and others (unpublished data, March, 1996) have used ${ }^{10} \mathrm{Be}$ and paleomagnetic analyses, which are supported by ${ }^{14} \mathrm{C}$-AMS and faunal data. This enabled them to mark the interglacial/glacial periods as the ${ }^{10} \mathrm{Be}$ concentrations are high during the inter-glacial episodes and correspondingly low for the glacial periods. The Gauss/Gilbert and Matuyama/Gauss boundaries are found at $631 \mathrm{~cm}$ and 450 respectively; the Brunhes chronozone is found in the upper $342 \mathrm{~cm}$ of the core. Frederichs (1995) provided both palaeomagnetic and oxygen isotope data, enabling correlation with younger cores. However, it should be noted that he only identifies the core to be as old as isotope Stage 23, which lies just above the Matuyama/Gauss boundary. This does not enable us to precisely date the DWAF in the whole of the core, as they occur above and below this level to the base. However, using magnetic events within the chronozones, Spielhagen's work provided an age of approximately 4.9 Ma. for the core base.

DWAF occur from the base of the core up until $105 \mathrm{~cm}$, occurring throughout the Gilbert, Gauss, Matuyama, and Brunhes chronozones. The presence of the DWAF at the base of the core, indicates that they are older than 3.5 Ma., as they occur below the Gauss/Gilbert chronozone boundary. The isotopic stages begin to correlate with the DWAF at $420 \mathrm{~cm}$ (text-fig. 9), which lies within isotopic Stage 23. This in an interglacial period, during which $C$. pusilla shows an abundance peak. This is followed by a low total abundance, corresponding with the glacial period, isotopic Stage $22(420-392 \mathrm{~cm})$. This is proceeded with an abundance peak in isotopic Stage 21, which in text-figure 9 is repre- 


\section{CORE PS2185-6 (KAL)}

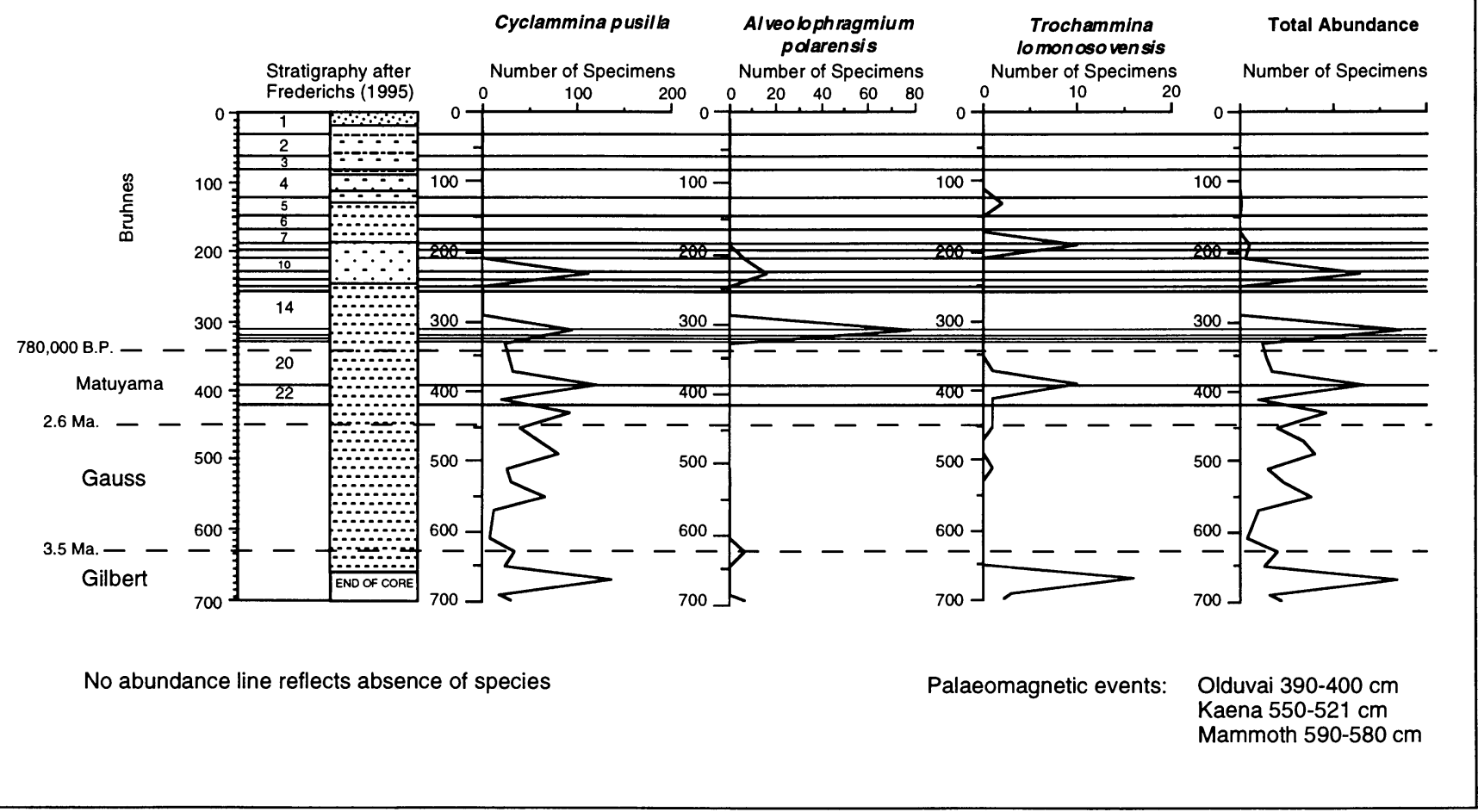

TEXT-FIGURE 9

Abundance of DWAF shown against isotopic stages for Core PS 2185-6 (KAL).

sented by a line. There is a period of low abundance of DWAF, corresponding with isotopic Stages 20, 19 (Brunhes/Matuyama boundary, 780,000 B.P.), 18, 17 and 16. This period ranges from $763-620 \mathrm{Ka}$. This is followed by the largest abundance peak in the core, represented by 175 specimens at $310 \mathrm{~cm}$, correlating with the interglacial isotopic Stage 15 (620-565 Ka.) Spielhagen's work proposed that this may be as a result of enhanced bioproduction. This is highlighted by high planktonic foraminifera abundance within ${ }^{10} \mathrm{Be}$-rich layers at $240,215,175,35 \mathrm{~cm}$ and in the core, corresponding with isotopic Stages 15, 13, 11, and 5 (text-fig. 9). It should be noted that these levels are at slightly different levels in the core to those proposed by Frederichs (1995) which are used for the purpose of this study. This is possibly due to data re-calculation. However, the DWAF do exhibit peaks at the Stages 15, 11 and 5 proposed by Frederichs (1995). Spielhagen indicated that these stages were identified as the only "very warm" interglacials in the Norwegian Sea during the last 600 kyr by Henrich and Baumann, (unpublished data). The DWAF are then absent from approximately 465-362 Ka., until they exhibit a peak at the top of isotopic stages 11 . There is then a further gap in the DWAF record until the middle of isotopic Stage 5. The peak is represented by only a few specimens of Trochammina lomonosovensis. This may correspond with the warmer interglacial periods of the Eamian, 5e or 5a. The DWAF do not occur above this point in the core.

The paleomagnetic analyses (variation of magnetic inclination) enabled Spielhagen and others to identify geomagnetic events within the core. They identified the main chronozone bounda- ries to be in the same position in the core as Frederichs (1995). It is therefore possible to describe the positions of the events. The first one identified from the base, in the Gilbert chron, was the Thvera event (500-485 Ka), followed by the Sidufjall (447-432 $\mathrm{Ka})$, Nunivak (420Ka-405 Ka), and Cochiti (390-380 Ka), marking the end of the Gilbert chron. The end of the Nunivak event corresponds with a DWAF peak at $670 \mathrm{~cm}$. This may be related to the environmental conditions prevailing during the duration of the event. The middle of the Gauss chron is marked two events, the Mammoth and Kaena. These do not appear to correlate well with any DWAF record. The two final events identified in their study, the Olduvai and Jaramillo, are within the Matuyama chron. Both of these precede peaks of DWAF, which may suggest that they had some climatic impact, resulting in higher organic flux, therefore enabling the DWAF to support to a larger living population.

\section{Paleoecology and Paleoceanography}

\section{Core PS2200-5 - Morris Jesup Rise}

The ecological characteristics of modern living benthic foraminifera, including DWAF, are directly comparable with those from the Pleistocene. This principal was used by Murray (1991) and it is from this data base that the paleoecological characteristics of the genera are taken for this study.

The dominant genus in the core is Cyclammina and it is present from the base of the core, to Sample $168 \mathrm{~cm}$. Murray (1991) suggested that this is epifaunal and lives free on mud or sand on the 


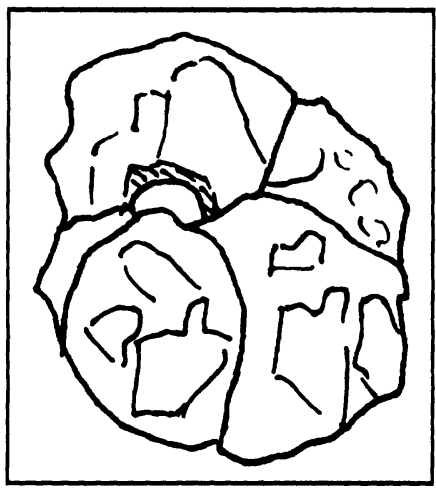

TEXT-FIGURE 10

Trochammina lomonosovensis camera-lucida sketch showing the position and characteristics of the aperture. The aperture is situated one quarter to half the way along between the axial depression and test periphery. Umbilical region is tight.

outer shelf to abyssal plain. This can be further refined, indicating that it is present on the lower slope = lower bathyal $(2000$ $4000 \mathrm{~m})$ and also on the abyssal plain $(4000 \mathrm{~m})$.

The genus Alveolophragmium has a Recent ecological habitat of a deep water environment and is epifaunal. Kaminski et al. (1988), found that such forms are epifaunal, living in the top $2 \mathrm{~cm}$ of the sediment. The genus Psammosphaera, represented by the third most dominant species, is probably an opportunistic species (Kaminski et al. 1988), suggesting that the species was able to survive in a disturbed environment. We assume that other genera present in the assemblage will have had similar ecological characteristics, for example, Rhabdammina is believed to be epifaunal, suspension-feeding group according to the morphogroup classification of Jones and Charnock (1985). In the Paleogene and Cretaceous high numbers of Glomospira reflect high organic productivity, (Kuhnt and Kaminski 1989, Kaminski et al. 1989). However, as there are only six specimens of this genus, this is probably not the case for this core. Trochammina lomonosovensis occurs at the youngest horizon in the core, its abundance varies and peaks at 16 specimens in Sample $671 \mathrm{~cm}$. This value correlates with the highest value for $C$. pusilla, suggesting that both species have similar ecological characteristics.

Cronin et al. (1995) indicate that for the ostracoda in Core PS2200-5, comparisons with closest modern analogues suggested that deep-water assemblages such as this one, lived at shallower depths $(1073 \mathrm{~m})$. Cronin et al. (1995) also noted that whilst the precision of paleobathymetric estimates require improvements, it is clear that the predominance of deep-water ostracod assemblages in the core contrast with typical diverse, bathyal assemblages characteristics of warm interglacials. The DWAF appear to show a similar pattern to the behaviour of the ostracoda where the DWAF in Core PS2200-5 are present in the interglacial periods, however, they are not preserved during the colder, glacial periods. It should be noted that even though the DWAF do not occur in significant numbers in the upper $20 \mathrm{~cm}$ of the core, Cronin et al. (1995) suggest that the increase of the most notable ostracod oceanographic indicator for this period, Acetabulastoma arcticum, in the upper $5-8 \mathrm{~cm}$ of Core PS2200-4 also from the Morris Jesup Rise, might signify the evolution of extensive perennial sea ice during the last 4000-
TABLE 1

Showing the location, water depth and core recovery.

\begin{tabular}{||c|c|c|c|c|c||}
\hline CORES & Location & Latitude & Longitude & Water Depth & Recovery \\
\hline PS 2177-5 & $\begin{array}{c}\text { Lomonosov } \\
\text { Ridge }\end{array}$ & $88^{\circ} 2.1^{\prime} \mathrm{N}$ & $134^{\circ} 36.7^{\prime} \mathrm{E}$ & $1400 \mathrm{~m}$ & $6.94 \mathrm{~m}$ \\
\hline PS 2200-5 & $\begin{array}{c}\text { Morris Jesup } \\
\text { Rise }\end{array}$ & $85^{\circ} 19.4^{\prime} \mathrm{N}$ & $14^{\circ} 00.0^{\prime} \mathrm{W}$ & $1073 \mathrm{~m}$ & $7.70 \mathrm{~m}$ \\
\hline PS 2212-3 & $\begin{array}{c}\text { Yermak } \\
\text { Plateau }\end{array}$ & $82^{\circ} 4.2^{\prime} \mathrm{N}$ & $15^{\circ} 51.2^{\prime} \mathrm{E}$ & $2550 \mathrm{~m}$ & $7.70 \mathrm{~m}$ \\
\hline PS 2185-6 & $\begin{array}{c}\text { Lomonosov } \\
\text { Ridge }\end{array}$ & $87^{\circ} 32.2^{\prime} \mathrm{N}$ & $144^{\circ} 55.6^{\prime} \mathrm{E}$ & $1052 \mathrm{~m}$ & $8.20 \mathrm{~m}$ \\
\hline
\end{tabular}

5000 years. This relationship is based on work on the Arctic and Iceland regions, where the species is found in sediments when sea-ice is present and its occurrence with ice-rafted shallow water ostracodes. (T.M. Cronin, personal communication, November, 1995). We suggest that this can be correlated with Core PS2200-5 as the two are from the same geographic area. In addition, using ostracod biofacies, Cronin et al. (1994), suggest that the Morris Jesup Rise would have been affected by the Lower Intermediate Eurasian water mass.

We conclude from the paleoecological data that the DWAF lived in a bathyal environment, the water chemistry was corrosive, preventing the preservation of calcareous benthic foraminifera, and it may have been a disturbed environment, reflected by the low number of DWAF present compared with a modern Arctic assemblage.

\section{Core PS2212-3 - Yermak Plateau}

The dominant genus Alveolophragmium, has a modern ecology of being epifaunal, living free on sand and is a marine dtritivore (Murray 1991). The other genera present are the same as Core PS2200-5 and therefore the DWAF would have lived in similar environment. In accordance with the ostracod data from Cronin et al. (1995), the upper $10 \mathrm{~cm}$ of the core, may represent a period during which perennial sea ice was evolving, this was during the last 4000-5000 years, (see previous). The study of nannofossils from a core by Nowaczyk et al. (1994), indicated that the area was affected by the Norwegian - West Spitsbergen current system. This was responsible for the introduction of nannofossils to the area. In addition, using ostracod biofacies, Cronin et al. (1994), suggest that the Yermak Plateau would have been affected by the deep Nansen Basin water mass.

\section{Core PS2185-6 - Lomonosov Ridge}

Core PS2200-5, this core is dominated by the genus Cyclammina. Murray (1991) suggested this would imply that the DWAF inhabited a bathyal, disturbed environment. The other genera present in the core are the same as at Morris Jesup Rise, suggesting that environmental conditions were similar.

Cores PS2200-5 and PS2185-6, were collected from the top of their respective ridges, and exhibit relatively high abundance of DWAF. We suggest that DWAF prefer a relatively bathymetrically shallower environment in the central Arctic Ocean, i.e. at depths between $\sim 1000-1400 \mathrm{~m}$. This is based on Core PS2212-3 (water depth $2550 \mathrm{~m}$, Yermak Plateau). This may indicate that the DWAF were not able to sustain a large population at deeper localities. This data corresponds with that proposed by Scott and Vilks (1991), where they observed diverse agglutinated foraminifera in Recent sediments of the Fram strait at depths between $800-1000 \mathrm{~m}$. Therefore, this study extends the bathymetric range of the DWAF in the region. Core PS2177-5, 
TABLE 2

Presence of agglutinated foraminifera in the core.

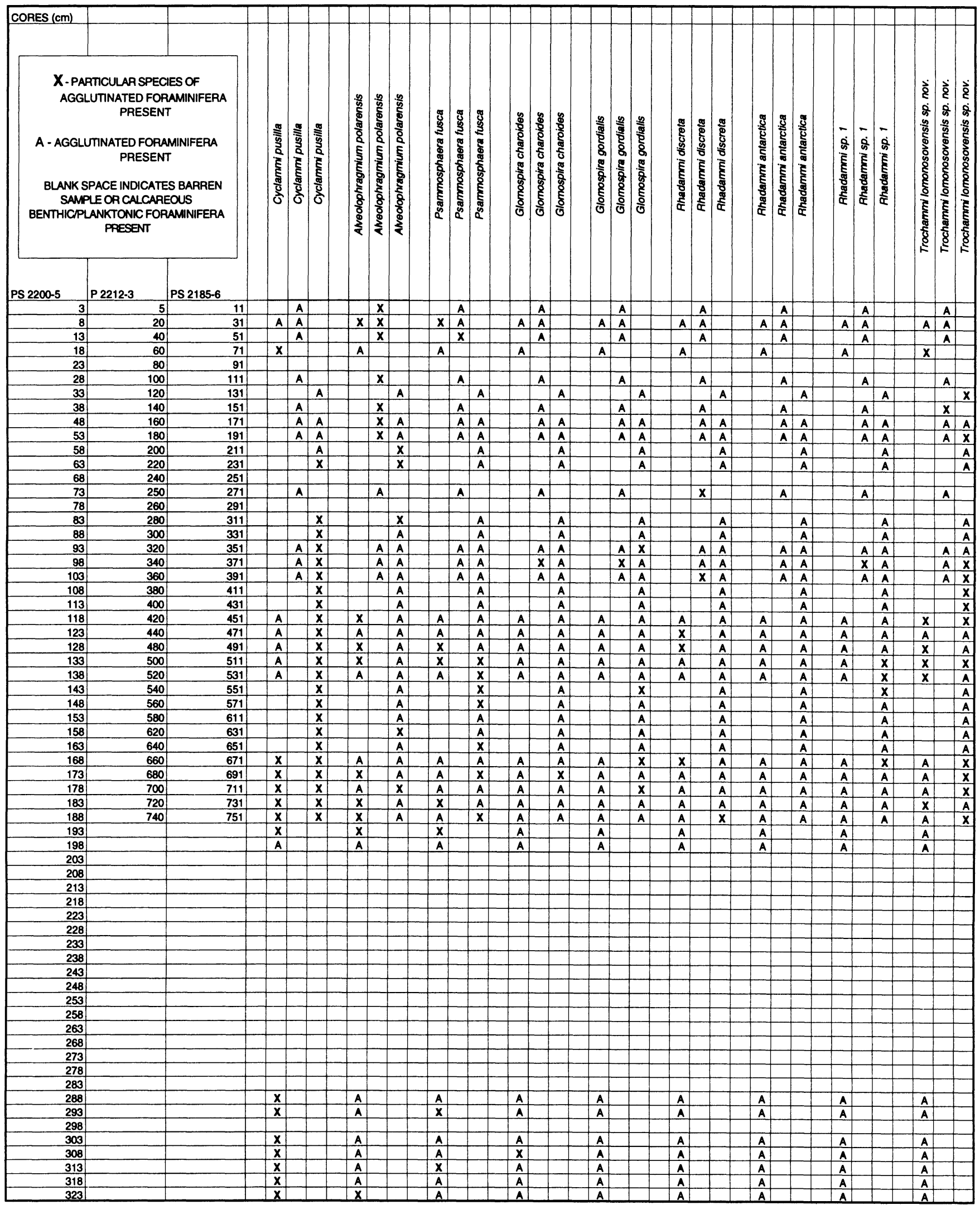


TABLE 3

Presence of agglutinated foraminifera in the core.

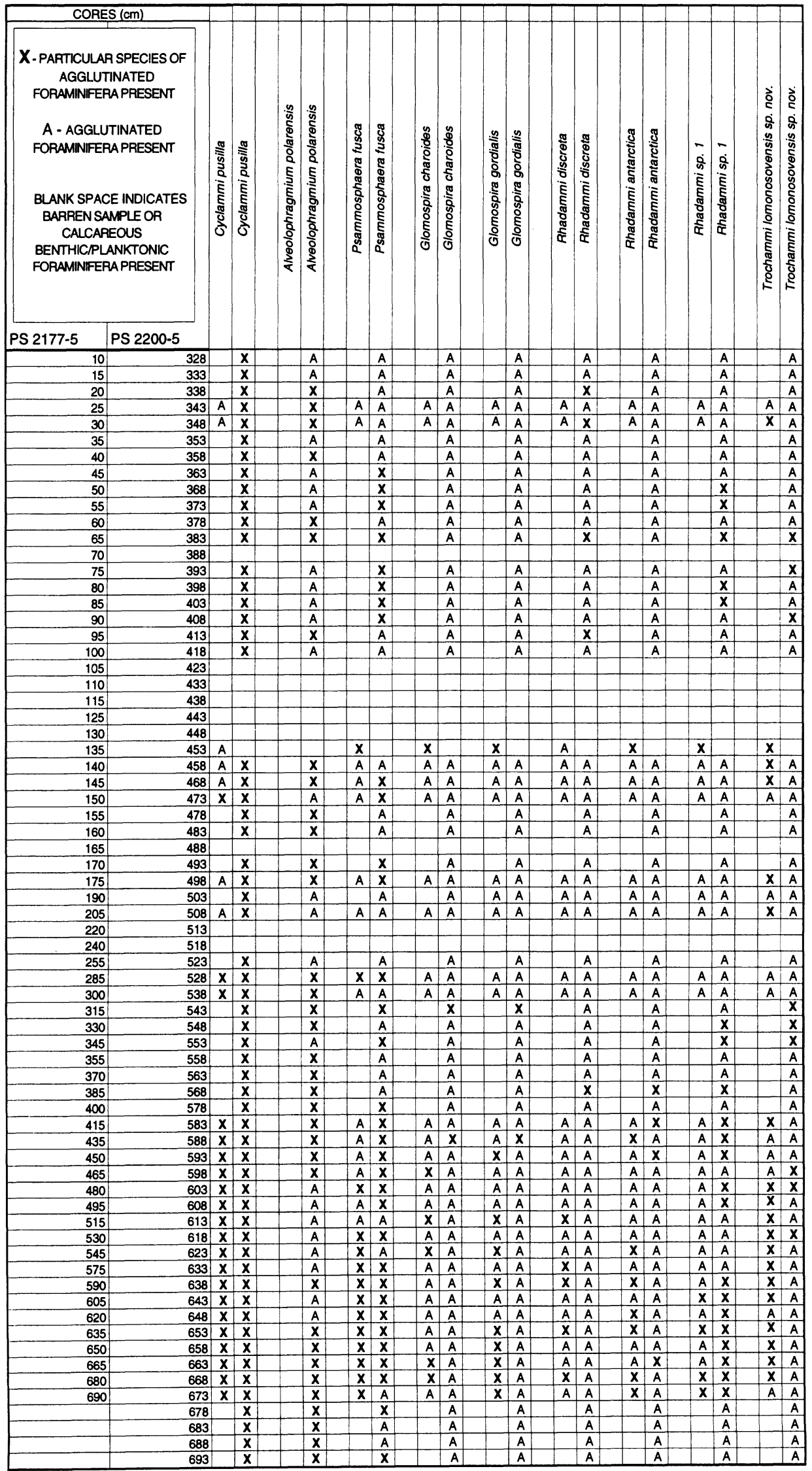


[1400m] from the Lomonosov Ridge contained abundant DWAF, whereas Core PS2176-3, [4363m], from the Amundsen Basin was nearly devoid of DWAF. As the DWAF observed in the cores are not confined to narrow depth ranges, it is not possible to construct a palaeobathymetrical zonation, as has been done by Cronin et al. (1995) using the ostracoda. Core PS2185-6 would have been affected by the Lower Intermediate Eurasian water mass.

We agree with Cronin et al. (1995), that the late Quaternary oceanographic history of the Arctic Ocean was complex. The DWAF present evidence to suggest that changes occurred during the last deglaciation and preceding glacial and interglacial periods (Holocene). These may have both been triggered by the formation of Arctic water masses, their changing strength and the increased effect of inflowing Atlantic water. However, further study needs to be carried out to investigate the connections between the areas, so that a more complete model can be generated for the oceanographic development of the Arctic Ocean using the DWAF.

\section{CONCLUSIONS}

DWAF were analysed from Cores PS2200-5, PS2212-3 and PS2185-6 from the central Arctic Ocean. These were collected during the ARK-VIII/3 cruise in the Summer of 1991 and range in age from early Pliocene to latest Pleistocene. Graphic lithology and the abundance of the DWAF are given for the three cores. Abundance fluctuations correspond closely with isotopically determined glacial/interglacial cycles, with peak abundances generally corresponding to warm (interglacial) conditions. We believe that the interglacial/glacial stages can be recognised in Arctic sediments using the DWAF abundance fluctuations alone, without isotopic records from calcareous benthic and planktonic foraminifera. This highlights the importance of the agglutinated foraminifera and proves that they even though they may be low in numbers in the central Arctic Ocean, they deserve equal study to that of the calcareous benthic and planktonic foraminifera.

We reinterpret the chronostratigraphy of Core PS2200-5 from the Morris Jesup Rise, based on DWAF evidence to suggest that sediments at the base of the core correlate with isotopic Stage 16. This refines the previous age model based on paleomagnetic stratigraphy, and AMS ${ }^{14} \mathrm{C}$ dating. We have calibrated the DWAF record with the paleomagnetic framework in Core PS2185-6 from the Lomonosov Ridge, extending the Arctic DWAF record to the lower Pliocene.

The paleoenvironmental data is interpreted from the three cores, concluding that on the basis of the paleoecology of the dominant genera present, the DWAF lived in a bathyal environment, which was at times disturbed and was generally not advantageous to the preservation of calcareous benthic foraminifera.

The taxonomy of the 11 DWAF species found in the studied cores is presented and illustrated. This includes a new species from the Family Trochamminidae, Trochammina lomonosovensis.

Further study is required to generate a more complete database of the DWAF from the central Arctic Ocean. This will provide more concrete evidence for the chronostratigraphy of the central Arctic Ocean, the behaviour of the DWAF, and the oceano-
TABLE 4

Barren samples in the core.

\begin{tabular}{|c|c|c|}
\hline \multirow{2}{*}{\multicolumn{3}{|c|}{\begin{tabular}{|l|l|}
\multicolumn{3}{|c|}{ BARREN SAMPLES } \\
CORES $(\mathbf{c m})$
\end{tabular}}} \\
\hline & & \\
\hline PS 2200-5 & PS 2212-3 & PS 2185-6 \\
\hline 28 & 60 & 31 \\
\hline 38 & 200 & 51 \\
\hline 48 & 220 & 91 \\
\hline 53 & 240 & 111 \\
\hline 58 & 380 & 151 \\
\hline 63 & 400 & 251 \\
\hline 68 & 420 & 271 \\
\hline$\overline{73}$ & 440 & 291 \\
\hline 78 & 480 & \\
\hline 83 & 500 & \\
\hline 148 & 520 & \\
\hline 153 & 540 & \\
\hline 158 & 640 & \\
\hline 208 & 660 & \\
\hline 213 & 680 & \\
\hline 218 & & \\
\hline 223 & & \\
\hline 228 & & \\
\hline 243 & & \\
\hline 248 & & \\
\hline 253 & & \\
\hline 258 & & \\
\hline 268 & & \\
\hline 273 & & \\
\hline 278 & & \\
\hline 283 & & \\
\hline 423 & & \\
\hline 433 & & \\
\hline 438 & & \\
\hline 443 & & \\
\hline 448 & & \\
\hline 453 & & \\
\hline 458 & & \\
\hline 463 & & \\
\hline 513 & & \\
\hline 518 & & \\
\hline
\end{tabular}


graphic factors affecting their development during the Neogene.

\section{TAXONOMY}

A list of barren samples and samples with calcareous benthic foraminifera and planktonic foraminifera are given in Tables 4 and $5 / 5 \mathrm{~A}$ respectively.

Order FORAMINIFERIDA Eichwald 1830

Suborder Allogromiina Loeblich and Tappan 1961

Superfamily Astrorhizacea Brady 1881

Family Rhabdamminidae Brady 1884

Subfamily Rhabdammininae Brady 1884

Genus Rhabdammina Brady 1879

Rhabdammina antarctica Saidova 1975

Plate 1, figure 1, 2

Rhabdammina antarctica SAIDOVA 1975, pl. 2, fig. 1.

Material: Core PS2177-5, 32 specimens; Core PS2200-5, 1 specimens.

Horizon: Pliocene and Pleistocene, See Tables 2 and 3.

Description: Straight tube which is slightly inflated at the centre. Quartz grains of varying diameter, but generally of smaller dimensions at one end of the tube. Distance between the larger grains varies, grains are tightly packed and one layer thick on the wall. Sharp edges of the grains protrude. External surface of test is rough. Internal surface is smooth. Pelitic material between the grains is light brown. Wall thickness is $0.5 \mathrm{~mm}$.

Remarks: Saidova (1975) noted that this species is found in the upper bathyal zone of the Antarctic, Ross Sea, Bellinghausen Sea and Southern subtropics. This is the first report of this species in the Arctic, therefore, it has a bipolar distribution.

Dimensions: Smallest: Length $=0.26 \mathrm{~mm}$, Width $=0.14 \mathrm{~mm}$. Largest: Length $=0.64 \mathrm{~mm}$, Width $=0.24 \mathrm{~mm}$.

Rhabdammina discreta Brady 1881

Plate 1, figure 3

Rhabdammina discreta, BRADY 1881. Original designation, not illustrated. - BRADY 1884, pl. 22, figs. 8-10.

Material: Core PS2177-5, 10 specimens; Core PS2200-5, 28 specimens; Core PS2212-3, 10 specimens; Core PS2185-6, 1 specimen.

Horizon: Pliocene and Pleistocene. See Tables 2 and 3.

Description: The test is cylindrical and open at both ends, consisting of a straight or nearly straight tube. The test is segmented with annular constrictions, but with no internal partitions. Wall is several grains thick and finely cemented. Aperture is at the open end of the tube. All specimens present are broken.

Dimensions: Smallest: Length $=0.18 \mathrm{~mm}$, Width $=0.52 \mathrm{~mm}$. Largest: Length $=1.75 \mathrm{~mm}$, Width $=0.59 \mathrm{~mm}$.

Rhabdammina sp. 1

Plate 1, figure 4

Plesiotype: Sample Core PS2177-5, 690cm, Box 25, $1 \mathrm{a}$.
Material: Core PS2177-5, 6 specimens; Core PS2200-5, 71 specimens; Core PS2212-3, 4 specimens; Core PS2185-6, 8 specimens.

Horizon: Pliocene and Pleistocene. See Tables 2 and 3.

Description: Straight tube. The tube is even and the tube has an equal diameter along its length. Surface of the tube is even. The fine grained inter-granular cement is light brown. Grains are of similar dimensions along the length of the tube and one layer thick. Smooth internal surface. Wall thickness is $0.01 \mathrm{~mm}$, tube diameter $0.5 \mathrm{~mm}$.

Remarks: This species differs from Hyperammina with the absence of a proloculus. Rhabdammina antarctica appears to be very similar, however, the uniform grain size and absence of inflated region in this species distinguishes it. This species also occurs in Core PI-92-AR P39 from the Northwind Ridge, Canada Basin. Evidence from Cronin et al. (1994) suggests that the high abundance in Core PS2200-5 may be explained by the outflowing of water masses Northwest of the Fram Strait near the boundary between the outflowing Intermediate Arctic (200$800 \mathrm{~m}$ ) and Deep Arctic water masses. This would increase the amount of suspended food particles available and thus the productivity of the foraminifera.

Dimensions: Smallest: Length $=0.70 \mathrm{~mm}$, Width $=0.52 \mathrm{~mm}$. Largest: Length $=1.22 \mathrm{~mm}$, Width $=0.70 \mathrm{~mm}$.

Family Psammosphaeridae Haeckel 1894.

Subfamily PSAMMOSPHAERINAE Haeckel 1894.

Genus Psammosphaera Schulze 1875.

Psammosphaera fusca Schulze 1875, emend Heron-Allen and Earland (1913)

Plate 2, figure 9

Psammosphaera fusca SCHULZE 1875, p. 113, pl. 2, fig. 8a-f.

Material: Core PS2177-5, 64 specimens; Core PS2200-5, 215 specimens; Core PS2212-3, 5 specimens; Core PS2185-6, 50 specimens.

Horizon: Pliocene and Pleistocene. See Tables 2 and 3.

Description: Unilocular test which is spherical to sub-spherical. Comprised of sand grains cemented to an inner organic lining. The tests and grains vary in size. The wall is thicker than the grains and the inside of the wall is smooth. Aperture is a rounded large opening.

Dimensions: Smallest: Length $=0.4 \mathrm{~mm}$, Width $=0.4 \mathrm{~mm}$. Largest $=0.56 \mathrm{~mm}$, Width $=0.54 \mathrm{~mm}$.

Superfamily Ammodiscacea Reuss 1862.

Family Ammodiscidae Reuss 1862.

Subfamily Ammovertellininae Saidova 1981.

Genus Glomospira Rzehak 1885.

Glomospira charoides (Jones and Parker).

Plate 1, figure 7

Trochammina squamata var charoides JONES and PARKER 1860: no type figure given.

Glomospira charoides (Jones and Parker). BERGGREN and KAMINSKI 1990 pl. 1, fig. 2.

Material: Core PS2177-5, 23 specimens; Core PS2200-5, 3 specimens; Core PS2212-3, 1 specimen. 
TABLE 5

Showing samples containing calcareous benthic and planktonic foraminifera.

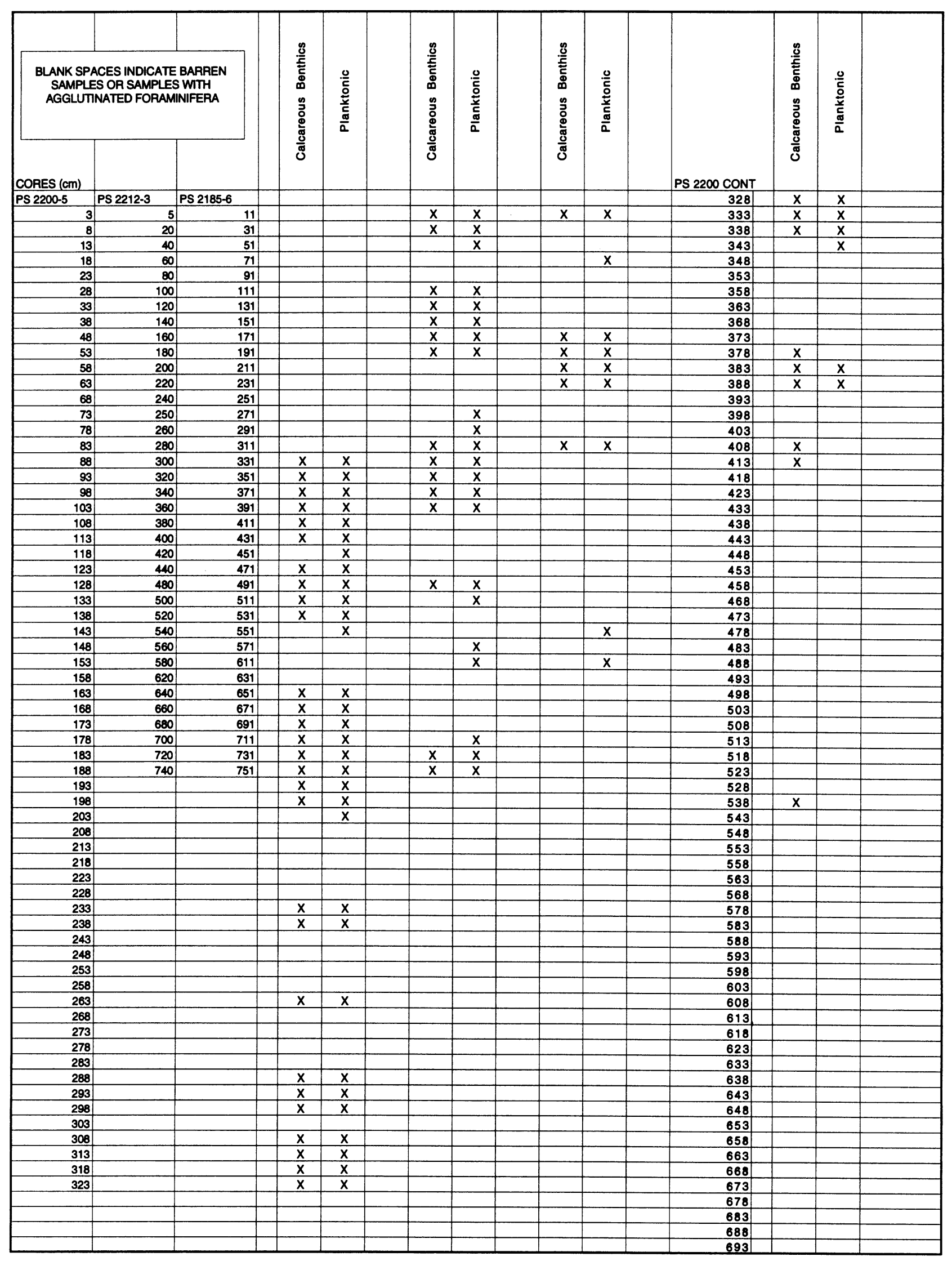


Horizon: Pliocene and Pleistocene. See Tables 2 and 3.

Description: Test free, proloculus followed by trochospirally enrolled, undivided tubular second chamber. This is coiled around a vertical axis. Test is comprised of approximately three coils. Finely agglutinate wall, smooth surface. Aperture at end of the tube.

Dimensions: Smallest: Length $=0.1 \mathrm{~mm}$, Width $=0.06 \mathrm{~mm}$. Largest: Length $=0.1 \mathrm{~mm}$, Width $=0.12 \mathrm{~mm}$.

Glomospira gordialis (Jones and Parker)

Plate 1, figures 5, 6

Trochammina squamata Jones and Parker var. gordialis JONES and PARKER 1860, no type figure given.

Glomospira gordialis (Jones and Parker). - BERGGREN and KAMINSKI 1990. pl. 1, fig. 1.

Material: Core PS2177-5, 36 specimens; Core PS2200-5, 3 specimens; Core PS2212-3, 3 specimens; Core PS2185-6, 5 specimens.

Horizon: Pliocene and Pleistocene. See Tables 2 and 3.

Description: Test comprised of proloculus, undivided tubular second chamber which is streptospirally coiled about a common plane. This occurs with five or six whorls of open coiling, not enrolled and umbilicus is usually visible and depressed. Final part of tube may be irregular. Wall is finely imperforate, finely agglutinated with a smooth finish. Aperture is at open end of tube.

Dimensions: Smallest: Length $=0.08 \mathrm{~mm}$, Width $=0.08 \mathrm{~mm}$. Largest: Length $=0.14 \mathrm{~mm}$, Width $=0.2 \mathrm{~mm}$.

Superfamily Cyclolinacea Loeblich and Tappan , 1964.

Family Cyclamminidae Marie 1941.

Subfamily Cyclammininae Marie 1941

Genus Cyclammina Brady 1879

Cyclammina pusilla Brady 1881

Plate 1, figures $8,9,10$

Cyclammina pusilla BRADY 1881, p. 53. - BRADY 1884, p. 354, pl. 37 , figure $20,21$.

Material: Core PS2177-5, 697 specimens; Core PS2200-5, 4002 specimens; Core PS2185-6, 1209 specimens.

Horizon: Pliocene and Pleistocene. See Tables 2 and 3.

Description: Biconvex test. Depressed at the umbilicus with a sharp slightly lobulate periphery. Three complete whorls, the last of which has ten to fifteen segments. Alveolar structure is poorly developed. Sutures are depressed and vary from straight to sigmoidal. The sutures are not always visible in the specimens and the grains are moderately coarse, densely packed and tightly cemented. Grains consist of quartz and black mafic fragments. Cement is light brown in colour. Walls thin. Inner surface shows a simple structure labyrinthic structure (small pseudo pores). Little variation grain size between the specimens.

Remarks. Our specimens are smaller and more coarsely agglutinated than the syntype specimens of $C$. pusilla [from CHALLENGER Station 323 in the South Atlantic] preserved in the Brady Collection, Natural History Museum, London. As a re- sult the sutures are not as clearly defined. The species is apparently common in the polar regions, as Earland (1934) reported it as "abundant in deep-water clays" from the Weddell Sea.

Dimensions: Smallest: Length $=0.29 \mathrm{~mm}$, Width $=0.26 \mathrm{~mm}$. Largest: Length $=0.66 \mathrm{~mm}$, Width $=0.64 \mathrm{~mm}$.

Suborder Trochamminina Brönnimann and Whittaker 1988

Superfamily Trochamminacea Schwager 1877, (emended Brönnimann, Zaninetti and Whittaker 1983, emended Brönnimann and Whittaker 1990)

Family Trochamminidae Schwager 1877, emended Brönnimann, Zaninetti and Whittaker 1983

Subfamily Trochammininae Schwager 1877, emended Brönnimann and Whittaker 1988

Genus Trochammina Parker and Jones 1859, emended Brönnimann and Whittaker 1988

Trochammina lomonosovensis Evans and Kaminski n. sp.

Plate 2, figures 1, 2, 3, 4

Holotype: Sample PS2177-5, 545cm from a site on the Lomonosov Ridge situated at $88^{\circ} 2.1^{\prime} \mathrm{N}, 134^{\circ} 36.7^{\prime} \mathrm{E}$, water depth of $1400 \mathrm{~m}$, sediment recovered $6.94 \mathrm{~m}$. Deposited in the Micropaleontology collections of the NHM, London, Cat. nos.: PF66744 (Holotype) and PF66745 (Paratype).

Diagnosis: Trochospiral, rounded and compact test. Four to four and a half chambers in final whorl on umbilical side, one interiomarginal aperture.

Derivation of name: Lomonosov Ridge, central Arctic Ocean, where it was found in abundance and where its characteristic aperture was observed.

Material: Core PS2177-5, 102 specimens; Core PS2200-5, 21 specimens, Core PS2185-6, 32 specimens.

Horizon: Pliocene and Pleistocene. See Tables 2 and 3.

Description: Test free, rounded and compact in outline, concavo-convex in shape, not watch-glass like. Wall coarsely agglutinated, giving the specimen a "blocky" appearance, imperforate and single layered. Wall has inner and outer organic sheets. Spiral side, low convex, coiling not easily visible. Proloculus is small and difficult to see because the surface of the test is obstructed with sediment or is smoothed, therefore, total number of chambers in the test not given. On umbilical side four to four and a half chambers are visible in the final whorl, the ultimate chamber is the largest and embraces the second and third chambers. Trochospiral coiling, compressed to rounded periphery. Chambers are subrounded. One aperture present, simple semi-circular opening, interiomarginal, resting on first/second chambers in the final whorl.

Remarks: Brönnimann and Whittaker (1988) indicated that the presence of single interiomarginal aperture distinguishes the Trochamminiae from the other five sub-families of the Trochamminidae. Trochammina subglobigeriniformis Mikhalevich (1972) has a single interiomarginal aperture, however, the chambers increase rapidly in size, the spiral side of the test is flat, the periphery is broadly rounded, and even though its single aperture rests on the first chamber in the final whorl, it has a rim, which is absent in T. lomonosovensis. The genus Trochammina is distinguished from the genus Deuterammina by the presence of its single aperture. The umbilical region in $\mathrm{Deu}$ - 
terammina is very open, the umbilical region has a star shaped aperture with a secondary preserved aperture at the umbilical end of the sutures (John E. Whittaker, personal communication). The genus Trochammina differs from the genus Paratrochammina as the aperture lies at the base of the septum, therefore is closed toward the axial cavity and does not communicate directly with it (Brönnimann 1979). However, in the description of Paratrochammina, Brönnimann indicated that its aperture extends beneath the septum from its points of attachment on the umbilical wall of the first chamber of the last whorl to that of the preceding chamber. Brönnimann and Whittaker (1988) remarked that this genus is distinguished from Portatrochammina by the absence of a porticus covering the umbilicus.

The size of the aperture varies in T. lomonosovensis. The holotype illustrated has a relatively large opening compared with compared with other specimens. The aperture is not clearly visible in all specimens, it is often blocked with detritus or sediment which may have been collected during the life of the foraminifera. It is also possible that this may be material collected by the foraminifera for building the test or next chamber. Modern species of Trochammina are known to live and reproduce within a loosely-built cyst of agglutinated material.

The holotype and specimens are from a water depth range of $1052 \mathrm{~m}$ (Core PS2185-6) to $1400 \mathrm{~m}$ (Core PS2177-5). This does not imply that $T$. lomonosovensis is restricted to this depth range, however, this remains to be seen from examination of additional core samples. This information is in contrast data from the Discovery Reports discussed by Brönnimann and Whittaker (1988). In the Southern Ocean the genus Trochammina was regarded as a deep water genera group, with a water depth of $3959-4845 \mathrm{~m}$. However, our records of T. lomonosovensis, is comparable with findings of Brönnimann and Whittaker (1988), with those of Shchedrina (1979), and the original depth range of $1800-3960 \mathrm{~m}$ given by Mikhalevich (1972) from the Antarctic. The evidence to suggest that $T$. lomonosovensis does not belong in the genus Paratrochammina or Deuterammina, is strengthened by the suggestion of Brönnimann and Whittaker (1990), that most Paratrochammina and Deuterammina are shallow-water forms.

Dimensions: Smallest: Length $=0.1 \mathrm{~mm}$, Width $=0.1 \mathrm{~mm}$. Largest: Length $=0.12 \mathrm{~mm}$, Width $=0.14 \mathrm{~mm}$.

Subfamily Alveolphragmiinae Saidova 1981

Genus Alveolophragmium Stschedrina 1936

Alveolophragmium polarensis O'Neill 1981

Plate 2, figure 5, 6, 7, 8

Alveolophragmium polarensis O’NEILL 1981 pl. 2, figs. 15, 16.

Material: Core PS2200-5, 744 specimens; Core PS2212-3, 95 specimens; Core PS2185-6, 120 specimens.

Horizon: Pliocene and Pleistocene, See Tables 2 and 3.

Description: Test free, multilocular. Planispiral, involute. Periphery rounded. Organic cement. Two whorls, with nine/ten chambers in final whorl. Outer whorl encompassed inner whorl. Umbilical region is smooth and rounded when viewed internally. Broad final chamber and large proloculus. Depressed sutures are seen in some specimens and are darker than chambers. Some specimens are coarsely agglutinated, which restricts viewing the sutures. Solid outer surface to test wall, with holes (alveoles) in the wall itself, internal section of wall is solid. The interior is complex, with the chamber walls often filled with holes. Many specimens are often coated with pyrite, giving a dark or black appearance. Aperture is equatorial, just above the base of the final chamber face, and a simple slit in the early chambers, later a linear series of irregular to rounded openings. Aperture is sometimes obscured by large sedimentary particles.

Remarks: In appearance this species is very similar to Cribrostomoides subglobosus forma subglobosus and is easily misidentified. However, further study has shown that its internal morphology separates the two species. Alveolophragmium polarensis differs from C. subglobosus forma subglobosus in the wall structure, with Alveolophragmium polarensis possessing holes in the wall and in the internal make up of the test. Many of the specimens examined are often less coarse than those illustrated by O'Neill (1981). It is observed that the smaller, possibly juvenile, specimens of this species have the same form of coiling, however, the aperture is more commonly a simple equatorial slit, whereas the larger specimens have simple slits and some have a series of irregular openings which make up the aperture.

Dimensions: Smallest: Length $=0.42 \mathrm{~mm}$, Width $=0.35 \mathrm{~mm}$, Aperture face view $=0.45 \mathrm{~mm}$. Largest: Length $=1.05 \mathrm{~mm}$, Width $=1.01 \mathrm{~mm}$, Aperture face view $=0.52 \mathrm{~mm}$.

\section{ACKNOWLEDGEMENTS}

We thank the Captain and crew of the R/V POLARSTERN and the scientific party of the ARK VIII/3 cruise and Dr. Thomas M. Cronin for supplying the study material. We are grateful to Dr. Thomas M. Cronin, (USGS, Reston, VA), Prof. Dr. Dieter Fütterer (Alfred-Wegener Institute, Bremerhaven); Dr. Thomas Frederichs (Universität Bremen), Dr. Christian Hass (U.C.L.) and Dr. Andreas Mackensen (A.W.I.) for reading and giving valued comments on draft versions of the manuscript; and in addition to. Dr. Scott Ishman, (USGS, Reston, VA,) for help and advice in the map included in this paper. We thank Dr. John Whittaker (NHM, London) for his taxonomic advice, and Toby Stiles and Jim Davy, (U.C.L.) for photographic and technical assistance. This is contribution number 51 of the Deep-Water Agglutinated Foraminifera Project. This work was carried out whilst the first author was in receipt of N.E.R.C. CASE Studentship GT4/93/214/G, co-sponsored by the USGS.

\section{REFERENCES}

BENDER, H., 1995. Test structure and classification in agglutinated foraminifera. In: Kaminski, M.A., Geroch S., and Gasinski M.A., Eds. Proceedings of the Fourth International Workshop on Agglutinated Foraminifera, Kraków, Poland, September 12-19, 1993. Grzybowski Foundation Special Publication 3: 27-68.

BERGGREN, W. A and KAMINSKI, M.A., 1990. Abyssal agglutinated: back to the basics. In Hemleben, C., Kaminski, M.A. Kuhnt, W., and Scott, D.B., Eds., Paleoecology, Biostratigraphy, Paleoceanography and Taxonomy of Agglutinated Foraminifera, 53-76. Kluwer Academic Publishers, Netherlands.

BERGSTEN, H., 1994. Recent benthic foraminifera of a transect from the North Pole to the Yermak Plateau, eastern central Arctic Ocean. Marine Geology 119: 251-267.

BRADY, H. B., 1879. Notes on some Reticularian Rhizopoda of the Challenger Expedition. Quarterly Journal of Microscopial Science, n. series, 19: 20-62. 
1881. On some Arctic Foraminifera from soundings obtained on the Austro-Hungarian North-Polar expedition of 1872-1874. Annals and Magazine of Natural History 8: 93-418.

1884. Report on the Foraminifera dredged by H.M.S. Challenger during the years 1873-1876. Zoology 9: 1-814.

BRÖNNIMANN, P., 1979. Recent benthonic foraminifera from Brazil Morphology and ecology. Part IV: Trochamminids from the Camos shelf with description of Paratrochammina n. gen. Paläont. Z. 53, 1 (2): 5-25.

BRÖNNIMANN, P. and WHITTAKER, J. E., 1988. The Trochamminacea of the Discovery Reports: A review of the Trochamminacea (Protozoa: Foraminiferida) described from South Atlantic and Antarctic waters by Heron-Allen and Earland (1932) and Earland (1933, 1934, 1936). British Museum (Natural History), London, 1988.

1990. Revision of the Trochamminacea and Remaneicacea of the Plymouth District, S. W.. England, described by Heron-Allen and Earland (1930). In: Hemleben, C., Kaminski, M.A., Kuhnt, W., and Scott, D.B., 1990. Paleoecology, Biostratigraphy, Paleoceanography and Taxonomy of Agglutinated Foraminifera: 105-137. Kluwer Academic Publishers, Netherlands.

BRÖNNIMANN, P., ZANINETTI, L., and WHITTAKER, J. E. 1983. On the classification of the Trochamminacea (Foraminiferida). Journal of Foraminiferal Research 13: 202-218.

CLARK, D. L., WHITTMAN R. R., MORGAN K. A., MACKEY S. D. Stratigraphy and glacial-marine sediments of the Amerasian Basin, Central Arctic Ocean. Geological Society of America Special Paper 181: $57 \mathrm{p}$

CRONIN, T. M., HOLTZ, T. R., and WHATLEY R. C. 1994. Quaternary paleoceanography of the deep Arctic Ocean based on quantitative analysis of Ostracoda. Marine Geology 119: 305-332.

CRONIN, T. M., HOLTZ, T. R., STEIN, R., SPIELHAGEN, R., FÜTTERER, D., and WOLLENBURG, J., 1995. Late Quaternary paleoceanography of the Eurasian Basin, Arctic Basin. Paleoceanography 10 (2): 259-281.

EARLAND, A., 1936. Foraminifera. Part IV. Additional records from the Weddell Sea sector from material obtained by the S.Y. 'Scotia'. Discovery Reports 13: 1-76.

EICHWALD, C. E., 1830. Zoologia specialis vol 2, Vilnae: D.E. Eichwaldus: 1-323.
EVANS, J. R., KAMINSKI, M. A., CRONIN, T. M. and FÜTTERER, D. K., 1995. Agglutinated foraminifera from the Lomonosov Ridge and Amundsen Basin, Arctic Ocean. Initial report on Piston Cores. Marine Micropaleontology 26: 245-253.

FREDERICHS, T., 1995. Regional and temporal variations of rock magnetic parameters in Arctic marine sediments. Berichte zur Polarforschung 164: 92-141.

FÜTTERER, D. K., 1992. ARCTIC ‘91: The Expedition ARK - VIII/3 of RV “Polarstern" in 1991. Berichte zur Polarforschung 107: 1-267.

GARD, G., 1988. Late Quaternary calcareous nannofossil biozonation, chronology and paleoceanography in areas north of the FaroeIceland Ridge. Quaternary Science Reviews 7: 65-78.

1993. Late Quaternary coccoliths at the North Pole: Evidence of ice-free conditions and rapid sedimentation in the central Arctic Ocean. Geology 21: 227-230.

GARD, G. and BACKMAN, J., 1990. Synthesis of Arctic and sub-Arctic coccolith biochronology and history of the North Atlantic drift water influx during the last 500,000 years. In: Bleil, U. and Thiede, J., (eds) Geological history of the polar oceans: Arctic vs. Antarctic. Dordrecht, Netherlands, Kluwer: 417-436.

HAECKEL, E., 1894. Systematische Phylogenie, Entwurf eines Natürlichen systems der Organismen auf Grund ihkrer Stammegeschichkte, Theil 1, Systematische Phylogenie der Protisten und Pflanzen. Berlin: Georg Reimer.

HERON-ALLEN, E. and EARLAND, A., 1913. The Foraminifera of the Clare Island District, Co. Mayo, Ireland [Clare Island Survey. Part 64. Foraminifera]. Proceedings of th Royal Irish Academy 31: 1-188.

JONES, T. R. and PARKER, W. K., 1860. On the rhizopodal fauna of the Mediterranean compared with that of the Italian and some Tertiary deposits. Quarterly Journal of the Geological Society of London 16: 292-307.

JONES R. W. and CHARNOCK M. A., 1985. "Morphogroups” of agglutinating foraminifera. Their life positions and feeding habitats and potential applicability in paleoecological studies. Revue de Paléobiologie 4: 311-320.

KAMINSKI, M. A., GRASSLE, J. F., and WHITLATCH, R. B., 1988. Life history and recolonization among Agglutinated Foraminifera in the Panama Basin. Abhandlungen der Geologischen Bundesanstat. A. $41: 229-245$.

\section{PLATE 1}

1,2 Rhabdammina antarctica Saidova 1975. 1, PS 2177-5 (KAL), Sample 590cm, x64. 2, Sample 635cm, x 100.

3 Rhabdammina discreta Brady 1881. PS 2200-5 (KAL), Sample 568cm, x43.

4 Rhabdammina sp. 1., PS 2200-5 (KAL), Sample $538 \mathrm{~cm}, \mathrm{x} 62$.
5,6 Glomospira gordialis (Jones and Parker). 5, PS 2177-5 (KAL), Sample $680 \mathrm{~cm}, \mathrm{x} 350$, side view. 6, PS 2177-5 (KAL), Sample $680 \mathrm{~cm}, \mathrm{x} 250$.

7 Glomospira charoides (Jones and Parker). PS 2177-5 (KAL), Sample $545 \mathrm{~cm}, \mathrm{x} 410$.

8-10 Cyclammina pusilla Brady 1881. 8, PS 2177-5 (KAL), Sample $545 \mathrm{~cm}$, x200, aperture face. 9, PS 2177-5 (KAL), Sample $590 \mathrm{~cm}$, x115, side view. 10, PS 2177-5 (KAL), Sample 590cm, x120. 

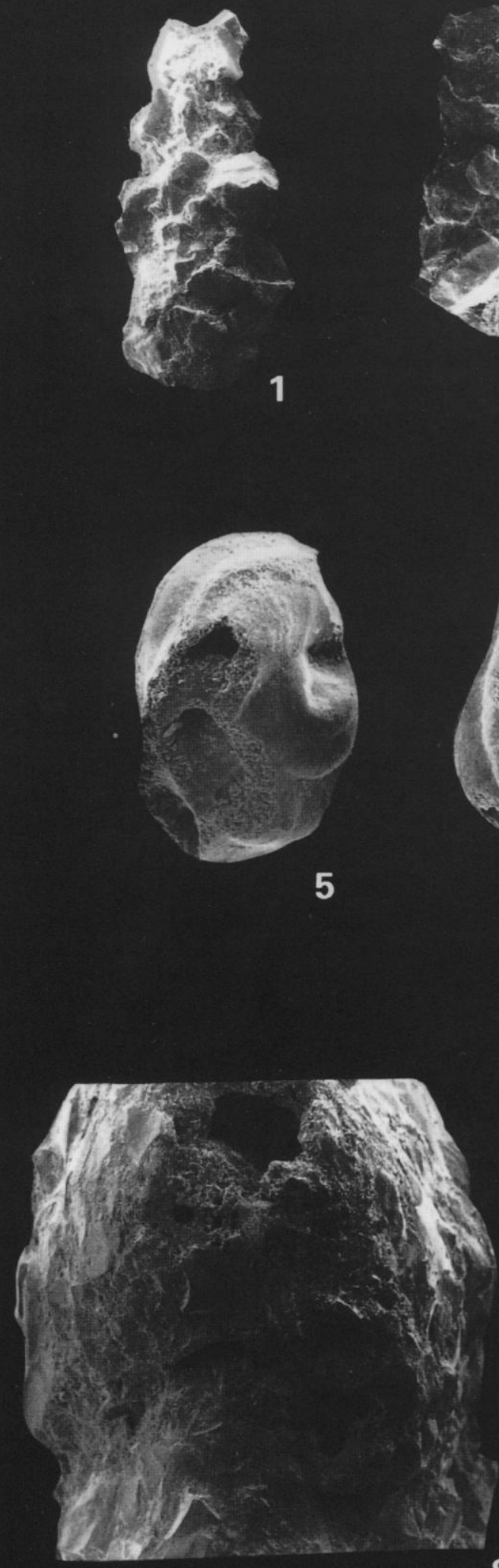

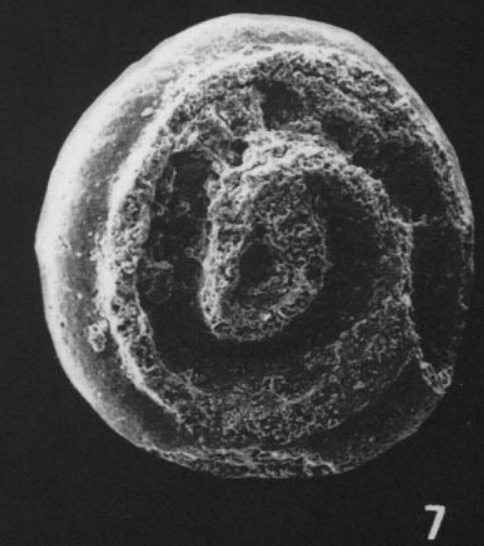

6

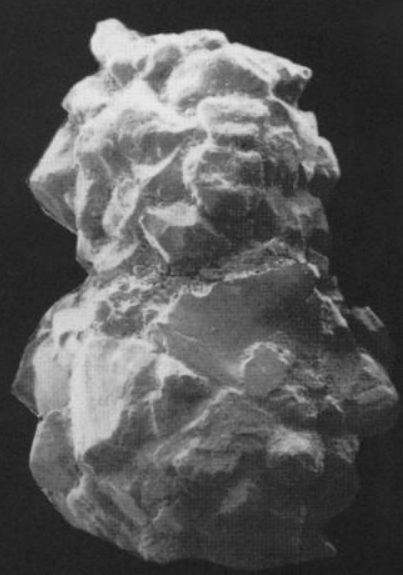

3

4

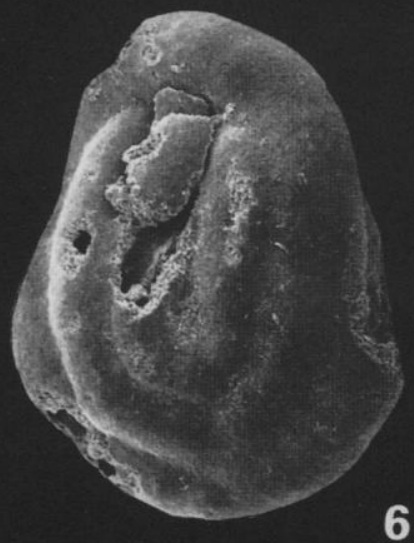

7

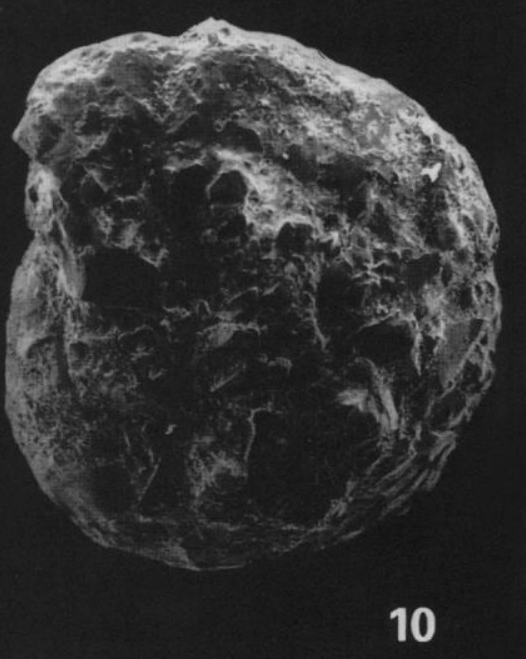


KAMINSKI, M. A., GRADSTEIN, F. M., SCOTT, D. B. and MACKINON, K. D., 1989. Neogene Benthic Foraminifera Biostratigraphy and Deep-Water History of sites 645, 646 and 647, Baffin Bay and Labrador Sea. Proceedings of Ocean Drilling Project Scientific Results, 105: 731-748.

$\rightarrow$ KEIGWIN, L. D., CURRY, W. R., LEHMAN, S. J., and JOHNSEN, S., 1994. The role of deep ocean in North Atlantic climate change between 70 and 130 kyr ago. Nature 371: 323-325.

KUHNT, W. and KAMINSKI, M. A., 1989. Upper Cretaceous deepwater agglutinated benthic foraminiferal assemblages from the Western Mediterranean and adjacent areas. In: J. Wiedmann (Editor), Cretaceous of the Western Tethys. Proceedings of the 3rd International Cretaceous Symposium, Tübingen, 1987. E. Schweizerbart' sche Verlagsbuchhandlung, Stuttgart, 91-120.

LAGOE, M. B. 1977. Recent Benthic Foraminifera from the Central Arctic Ocean. Journal Foraminiferal Research 7 (2): 106-129.

1979. Recent Benthonic foraminiferal biofacies in the Arctic Ocean. Micropaleontology 25: 214-224.

$\rightarrow$ LOEBLICH, A. R. Jr. and TAPPAN, H., 1961. Supragenic classification of the Rhizopodea. Journal of Paleontology 35: 245-330.

1964. Sarcodina, chiefly Thecamoebians and foraminifera. In Moore, R. C. (Ed.), Treatise on Invertebrate Paleontology. Geological Society of America and University of Kansas Press, New York and Lawrence, KS, Part C, Protista (2) 2, 2v., 900p.

1987. Foraminiferal genera and their classification. Van Nostrand Reinhold Co., New York, vol. 1, 970 pp.

$\rightarrow \longrightarrow, 1989$. Implications of wall compositions and structure in agglutinated foraminifers. Journal of Paleontology 63 (6): 769-777.

MAJZON, L., 1943. Adatok egyes Kárpatálijai Flisrétegekhez, tekintettel a Gobotruncanákra, A magyar Királyi Föltani Intézet, Évkönyve 37: $1-170$.

MARIE, P., 1941. Les Foraminifères de la Craie a Beleminitell mucronata du Bassin de Paris. Mém. Mus. natn. Hist. nat., Paris 12 (1): 1296.
MIKHALEVICH, V. I., 1972. Age variability of the Antarctic species of the genus Trochammina Parker and Jones and its significance for the taxonomy of the subfamily Trochammininae (Foraminifera). In Bychovskii, B.E. (Ed.), Biological results of the Soviet Antarctic Expeditions, 5. Issled Fauny Morei, Leningrad, 11 (19), text-figs 1-73. (In Russian).

MURRAY, J. W., 1991. The Ecology and Palaeoecology of Benthic Foraminifera. Longmans, London, pp. 324.

NOWACZYK, N. R. and BAUMANN, M., 1992. Combined highresolution magnetostratigraphy and nannofossil biostratigraphy for late Quaternary Arctic Ocean sediments. Deep-Sea Research 39. Suppl. 2 : S567-S601.

NOWACZYK, N. R., FREDERICHS, T. W., EISENHAUSER, A., and GARD, G., 1994. Magnetostratigraphic data from late Quaternary sediments from the Yermak Plateau, Arctic Ocean: Evidence for four geomagnetic polarity events within the last 170 kyrs of the Bruhnes Chron. Geophys. J. Int' 117: 453-471.

O'NEILL, B. J. 1981. Pliocene and Pleistocene benthic foraminifera from the central Arctic Ocean. Journal of Paleontology 55 (6): 11411170 .

PARKER, W. K. and JONES, T. R., 1859. On the nomenclature of the foraminifera II. On the species enumerated by Walker and Montagu. Annals and Magazine of Natural History Ser 3, 4: 333-351.

REUSS, A. E., 1862. Entwurf einer systematischen Zusammenstellung der Foraminiferen. Stizungsberichte der kaiserlichen Akademie der Wissenschafen 44 (1861): 355-396.

RZEHAK, A., 1885. Bemerkungen über einige Foraminiferen der Oligocän Formation. Verhandlangen des Naturforschenden Vereins in Brün (1884) 23: 123-129.

SAIDOVA, K. M., 1975. Benthonic foraminifera of the Pacific Ocean. Academy of Sciences of the USSR, P. PShirshov. Institute of Oceanology, Moscow 875 pp.

, 1981. On the current system of suprageneric classification of Cenozoic benthonic foraminifera. Academy of Sciences of the USSR, P. P Shirshov. Institute of Oceanology, Moscow. 73pp. (in Russian).
1 Trochammina lomonosovensis Evans and Kaminski, n. sp. Holotype. PS 2177-5 (KAL), Sample $545 \mathrm{~cm}$, $\mathrm{x} 300$, spiral view.

2 Trochammina lomonosovensis Evans and Kaminski, n. sp. Holotype. PS 2177-5 (KAL). Sample 545cm, $\mathrm{x} 300$, side view.

3 Trochammina lomonosovensis Evans and Kaminski, n. sp. Holotype. PS 2177-5 (KAL), Sample 545cm, x290, umbilical view.

4 Trochammina lomonosovensis Evans and Kaminski, n. sp. Holotype. PS 2177-5 (KAL), Sample 545cm, $\mathrm{x} 550$, close up of aperture.
5 Alveolophragmium polarensis O'Neill 1981. PS 2200-5 (KAL), Sample 568cm, x68, spiral view.

6 Alveolophragmium polarensis O'Neill 1981. PS 2200-5 (KAL), Sample 568cm, x70, aperture face view.

7 Alveolophragmium polarensis O'Neill 1981. 7, PS 2200-5 (KAL), Sample 568cm, x140, close up of apeture.

8 Alveolophragmium polarensis O'Neill 1981. 8, PS 2200-5 (KAL), Sample $348 \mathrm{~cm}$, x82, internal view showing coiling and chambers.

9 Psammosphaera fusca Schulze 1875. Emend. 9, PS 2177-5 (KAL), Sample 620cm, x100. Broken specimen. 

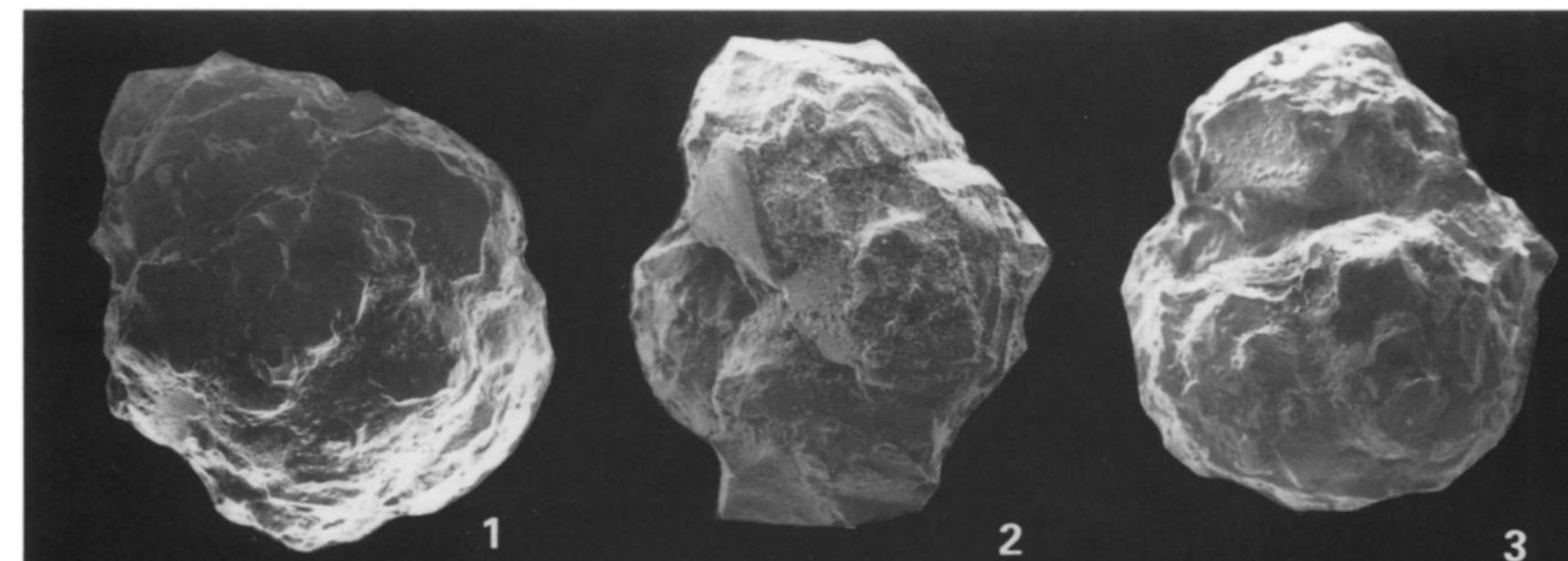

2
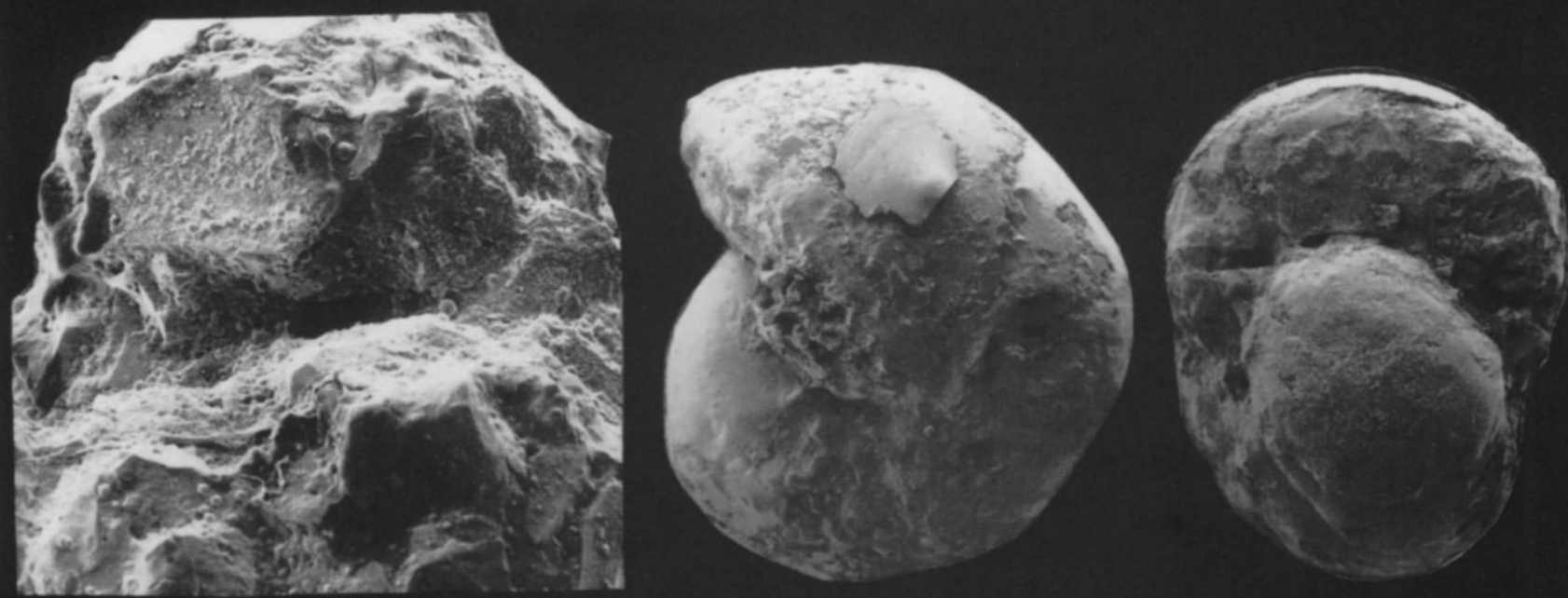

4

5
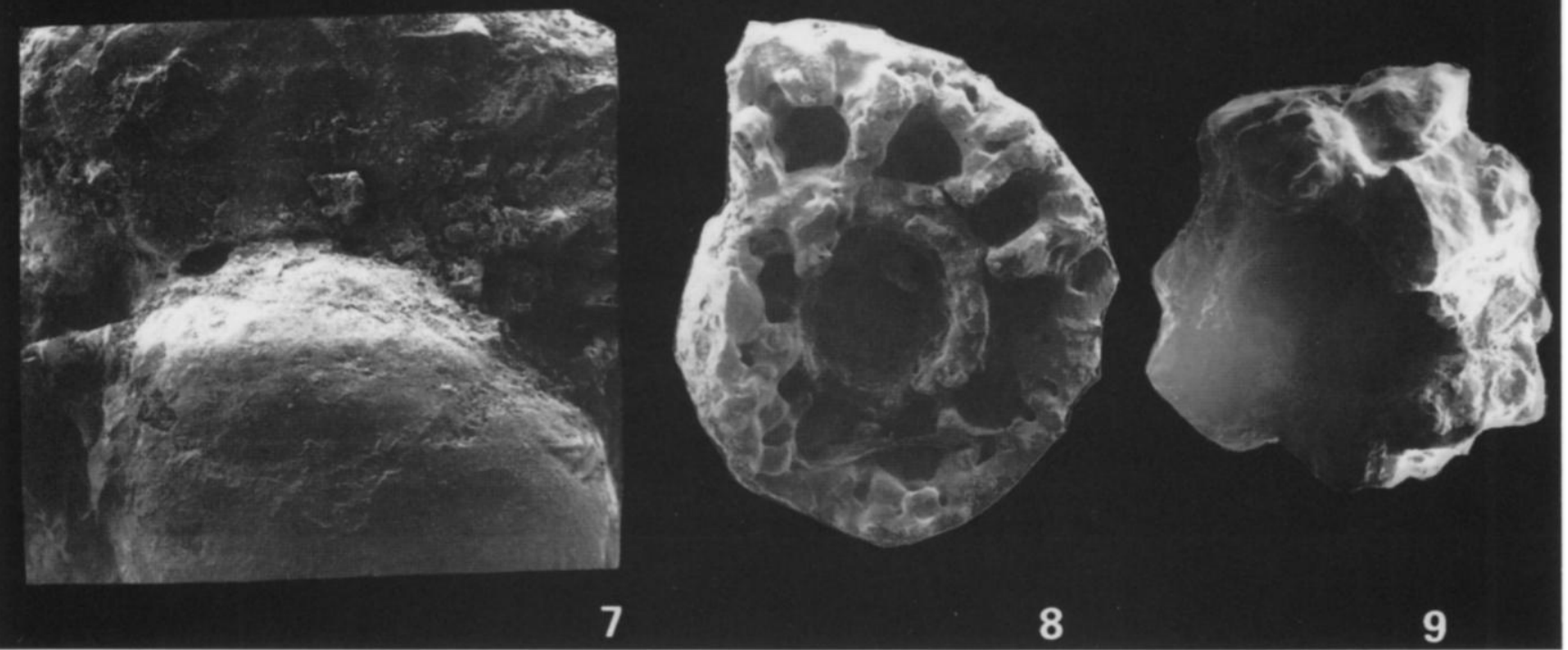
SCOTT, D. B., MUDIE, P. J., BAKI, V. MACKINNON, K. D. and COLE, F. E., 1989. Biostratigraphy and Late Cenozoic paleoceanography of the Arctic Ocean: Foraminiferal, Lithostratigraphic and isotopic evidence. Geological Society of America Bulletin 101: 260-277.

SCOTT, D.B. and VILKS, G. 1991. Benthonic foraminifera in the surface sediments of the deep-sea Arctic Ocean. Journal of Foraminiferal Research 21 (1): 20-38.

SCHRÖDER-ADAMS, C. J. and MCNEIL, D. H. 1994. Oligocene to Miocene agglutinated foraminifers in deltaic and deep-water facies of the Beaufort-Mackenzie Basin. Geological Survey of Canada Bulletin 477. 67pp.

SCHULZE, F. E., 1875. Zoologissche Ergebnisse über die Nordseefahrt vom 21. Juli bis 9. September 1872. I. Rhizopoden. Jarhresbericht der Commission zur wissenschaftlichen Untersuchung der deutschen Meere in Kiel für die Jahre 1872-1873, 99-114.

SCHWAGER, C., 1877. Quadro del proposto sistema di classificazione dei foraminiferi con guscio. Bulletino R. Comitato Geologico d' Italia 8: 18-27.
SHCHEDRINA, Z. G., 1936. Alveolophragmium orbiculatum nov. gen. nov. sp. Zoologischer Anzeiger 114: 312-319.

1979. Fauna of agglutinated foraminifera of the South Hemisphere from the material of the Soviet Antarctic Expedition (19551966). Antarktika, 18: 144-174, pls. 1-3. Moskow, (In Russian).

STEIN, R., SCHUBERT, C., GROBE, H. and FÜTTERER, D. K., 1993. Late Quaternary changes in sediment composition in the Central Arctic Ocean: Preliminary results of the Arctic ' 91 Expedition. In: D.K. Thurston and K. Fujita (Editors), Proceedings of the International Conference on Arctic Margins, Anchorage.

STEIN, R., SCHUBERT, C., VOGT, C. and FÜTTERER, D. K., 1994a. Stable isotope stratigraphy, sedimentation rates and paleosalinity changes in the Latest Pleistocene to Holocene central Arctic Ocean. In: J. Thiede, T.O. Vorren and R.F. Spielhagen (Editors), Arctic Ocean Marine Geology. Marine Geology 119: 333-355.

$\rightarrow$ STEIN, R., NAM, C., SCHUBERT, C., VOGT, C., FÜTTERER, D. K., and HEINEMEIER, J., 1994b. The last deglaciation event in the eastern central Arctic Ocean. Science 264: 692-696.

Manuscript received February 14, 1996

Manuscript accepted December 18, 1996 